Revista lus et Praxis, Año 19, No 1, 2013, pp. 139 - 194

ISSN 0717 - 2877

Universidad de Talca - Facultad de Ciencias Jurídicas y Sociales

"Una aproximación al sistema de imputación

subjetiva en el Derecho Penal anglosajón"

Nicolás Oxman

\title{
UNA APROXIMACIÓN AL SISTEMA DE IMPUTACIÓN SUBJETIVA EN EL DERECHO PENAL ANGLOSAJÓN*
}

\author{
AN APPROACH TO THE SUBJECTIVE \\ IMPUTATION SYSTEM IN ANGLO-AMERICAN CRIMINAL LAW
}

Nicolás OXMAN**

\begin{abstract}
RESUMEN
Como regla general, los sistemas jurídicos angloamericanos de Derecho Penal consagran estados mentales de culpabilidad (mens rea). Las categorías de mens rea de la mayoría de los delitos son: el dolo o propósito (que es el estado mental más reprochable), el conocimiento, la imprudencia y la negligencia criminal. En los sistemas jurídicos europeos de Derecho Penal el dolo es un nivel de imputación que no sólo se utiliza para los supuestos de propósito o de conocimiento, sino que, también, incluye casos que en los sistemas jurídicos angloamericanos de Derecho

Penal se denominan recklessness (imprudencia). Después de una revisión del concepto de culpabilidad en el common-law, esta investigación describe el concepto de dolo y del resto de categorías mentales de imputación.
\end{abstract}

ABSTRACT

As a general rule, the Anglo-American legal systems of criminal law stipulate a culpable state of mind (mens rea). The mens rea of most criminal offences are: intent or purposely (which is the most culpable mental state), knowledge, recklessness, and criminal negligence. In the European legal system of criminal law, intention is a label used not only for cases of purposely or knowledge; it's also includes cases of what the Anglo-American legal systems of criminal law would call recklessness. After a review of the common-law concept of culpability, this research shows the concept of intention and the others state of mind categories.

PalabRAS Clave

Culpabilidad, Dolo, Conocimiento, Imprudencia, Negligencia

KEYWORDS

Mens Rea, Intent, Knowledge, Recklessness, Negligent

* Trabajo recibido el 12 de diciembre de 2012 y aprobado el 19 de abril de 2013.

** Profesor de Derecho Penal, Universidad Santo Tomás, sede de Santiago; Doctorando en Derecho Penal por la Universitat de València. Correo electrónico: nicolas.oxman@uv.es. Trabajo realizado en el marco del proyecto I+D/DIP 68/2011 de la Universidad Santo Tomás, en una estancia de investigación en el Departament de Dret Penal de la Universitat de València. 


\section{INTRODUCCIÓN}

El principio de culpabilidad, más allá del concreto contenido que pueda dársele en los distintos sistemas del Derecho Penal es, como afirma Fletcher, una cuestión universal presente en todos los ordenamientos jurídicos ${ }^{1}$. Ahora bien, aunque en el common-law ${ }^{2}$ no se alude expresamente a éste porque se entiende que es una noción incorporada al sistema procesal de alegaciones y veredictos, la doctrina lo menciona, en el plano sustantivo, con términos que podrían ser calificados como neutros, prefiriendo utilizar la expresión "reprochabilidad" ${ }^{3}$. Ahora bien, su contenido y funciones deben calificarse, de entrada, como idénticas a las que cumple en nuestro sistema jurídico. A partir de este punto de vista, en el presente estudio se aborda desde una mirada general la noción de culpabilidad en el sistema anglosajón de Derecho Penal, dilucidando desde una aproximación conceptual cada una de las categorías de atribución de responsabilidad subjetiva que la componen. Desde ese lugar, se propone un primer análisis de relación con el Derecho Penal continental, incorporando, sólo a modo de ejemplo, las referencias doctrinales y jurisprudenciales más importantes, únicamente en los lugares en que lo he estimado prudente y en los puntos en que de alguna forma se ha intentado ya previamente un acercamiento de sistemas jurídico-penales por los autores de ambos espacios culturales, ya sea para proponer una diferenciación, o bien, una asimilación de las diversas categorías dogmáticas desarrolladas por ambas tradiciones jurídicas.

Contrariamente a lo que podría pensarse, la visión que se propone privilegia el análisis desde el sistema del common-law, ofreciendo desde ahí un punto de partida para un estudio posterior que se enfrente derechamente a una posible armonización de sistemas, tomando siempre como eje central los principios que son comunes. En efecto, ha sido Bernal del Castillo quien ha manifestado con notable claridad que junto con las diferencias existen muchas instituciones

1 Fletcher, George, Gramática del Derecho Penal, Francisco Muñoz Conde (trad.), Hamurabi, Buenos Aires, 2008, pp. 57 y 71.

2 Esta expresión se utiliza en el presente trabajo en el sentido que le asigna la doctrina norteamericana, es decir, como "un conjunto de costumbres jurídicas imperantes en la tradición angloamericana que encuentra su apoyo en normas de fundamento común y prácticas sociales que han servido para la evolución de las decisiones judiciales". SCHAmalleger, Frank, Criminal Law today: an introduction with capstone cases, $3^{\text {a }}$ Edición, Prentice Hall, New Jersey, 2006, p. 20.

3 Es la traducción del términos anglosajones "blameworthiness", "moral blame" o "guilty mind" (culpabilidad en sentido amplio), reservándose por algunos autores la palabra culpabilidad para referirse a los tipos específicos de mens rea establecidos en la ley (culpabilidad en sentido restringido). Así, por ejemplo, KAPLAN, John; WeISBERG, Robert; BINDER, Guyora, Criminal law: cases and materials, $5^{\text {a }}$ Edición, Aspen Publishers, New York, 2004, pp. 157 y ss. 
"Una aproximación al sistema de imputación subjetiva en el Derecho Penal anglosajón"

compartidas, "lo cual facilita disipar recelos sobre esa pretendida incompatibilidad de sistemas"

La idea de una vinculación más estrecha entre las tradiciones jurídico-penales más importantes de Europa no es un asunto reciente, pero sí se ha puesto de manifiesto a partir de una aproximación crítica de cara a una eventual futura armonización ${ }^{5}$, surgiendo también por la necesidad de dotar un sistema común de imputación para la resolución de casos en el Tribunal Europeo de Derechos Humanos ${ }^{6}$. Al mismo tiempo que se ha evidenciado en el debate sobre cuál es el modelo con el que deberían decidirse los asuntos sometidos al Tribunal Penal Internacional ${ }^{7}$. Dejando a un lado tales contingencias prácticas, parece haber algo que trasciende al presente y que se vincula con la idea de Radbruch ${ }^{8}$ de que los verdaderos progresos de la dogmática subyacen en la derrota de los obstáculos que existen para el avance del conocimiento conjunto e intercultural en el plano del Derecho, en cuanto ciencia social. De este modo, pese al hecho de que las disposiciones legales o las decisiones jurisprudenciales de todos los sistemas jurídicos, sean no sólo lingüística, sino que, también, fácticamente diferentes, está siempre en el debate jurídico el dilema común sobre cuáles son o han de ser los fines y funciones que se le han de atribuir al Derecho Penal en la sociedad actual ${ }^{9}$.

4 El mismo autor indica que por muchas que sean las diferencias entre los diversos ordenamientos jurídicos "no falta en ninguno de ellos la exigencia de un elemento de reproche subjetivo dentro del concepto del delito, Ilámese mens rea, elemento subjetivo del delito o culpabilidad", BERNAL DEL CASTILıo, Jesús, Derecho Penal comparado. La definición de delito en los sistemas anglosajón y continental, Ariel-Libros Jurídicos, Barcelona, 2011, p. 24 y pp. 90 y ss.

5 Cfr. Silva SÁnChez, Jesús María, "Los principios inspiradores de las propuestas de un Derecho Penal europeo. Una aproximación crítica". Revista Penal 3, 2004, pp. 138 y ss. Carnevali Rodrícuez, Raúl, Derecho Penal y Derecho sancionador de la Unión Europea, Comares, Granada, 2001, pp. 283 y ss. PerRón, Walter, "¿Son superables las fronteras nacionales del Derecho Penal? Reflexiones acerca de los presupuestos estructurales de la armonización y unificación de los diferentes sistemas de Derecho Penal", Revista de Derecho Penal y Criminología 2, 1998, pp. 209 y ss.

6 Ampliamente, Bernal del Castillo, Derecho Penal, cit. nota n. 4, pp. 53 y ss.

7 Así, Matus Acuña, Jean Pierre, La transformación de la teoría del delito en el Derecho Penal internacional, Ariel-Libros Jurídicos, Barcelona, 2008, pp. 17 y ss. VIADA, Natacha, Derecho Penal y globalización. Cooperación penal internacional, Marcial Pons, Madrid, 2009, pp. 40 y ss. AmBos, Kai, Temas de Derecho Penal internacional y europeo, Marcial Pons, Madrid, 2006, pp. 99 y ss.

${ }^{8}$ Radbruch, Gustav, "Jurisprudence in the Criminal Law", 18 J. Comp. Legis. \& Int'l L. 3d ser. 212, 1936, pp. 213 y ss.

9 De este modo, no parecen ayudar las posturas que intentan superponer un sistema jurídico sobre el otro. En esta línea, por ejemplo, se sitúa Ambos quien si bien parte de la idea de que "el Derecho Penal descansa sobre determinadas premisas filosóficas de validez universal", indica que una de tales premisas es la posibilidad del ser humano de actuar conforme a la determinación de la voluntad, con pleno conocimiento del significado de las acciones que realiza, agregando que es una cuestión innegable que el mayor "descubrimiento" y aporte de la ciencia del Derecho Penal alemán no es otro que la distinción 


\section{LA CULPABILIDAD COMO PRINCIPIO DE IMPUTACIÓN EN EL COMMON-LAW}

Según indica Herring ${ }^{10}$ en las leyes inglesas del siglo XII, durante el reinado de Henry I, se acuñó en el Derecho Penal del Reino Unido una locución latina que sintetiza la cuestión sobre la necesidad de acreditar el estado mental con que obró el sujeto al momento de la realización del hecho, asunto que, al mismo tiempo, resume todo el sistema penal del common-law en la máxima: "actus non facit reum, nisi mens sit rea" (esto es, la realización de un hecho no hace a una persona culpable a menos que la mente también lo sea). A partir de ese momento, se fue forjando por la tradición jurisprudencial inglesa un sistema de imputación penal bipartito cuya estructura de análisis se basa en la distinción entre, por una parte, un aspecto externo-objetivo referido a la conducta que se sintetiza en el término actus reus y, por otra parte, un ámbito interno-subjetivo que alude a la idea de la necesidad de vinculación entre la conducta y la mente, como una cuestión que no sólo permite un constructo de racionalidad para poder afirmar o negar de forma fehaciente en el proceso que el acusado ha obrado de un modo reprochable, sino que, también, como un reflejo de la graduación de la intensidad del juicio de reproche ${ }^{11}$. Lo anterior, se concreta en diferentes estados mentales que se agrupan bajo el amplio concepto de mens rea (expresión latina sinónima de "mente culpable"), cuyo contenido se relaciona con la idea de libertad de la voluntad ${ }^{12}$.

entre, por un lado, el elemento mental (el dolo) como categoría de la acción y, por ende, de la tipicidad, o bien, si se quiere como parte del injusto -en uno de los tipos de sistemas bipartitos de la teoría del delito- $y$, por el otro, la culpabilidad en un sentido normativo que justifica el juicio de reproche personal al autor sobre la consideración sobre si en las circunstancias concretas en las que actuó le era o no exigible haber obrado de otro modo. Amвоs, Kai, "Dogmática jurídico-penal y concepto universal de hecho punible", Política Criminal 5, 2008, pp. 11 y ss. En el otro extremo se sitúa Dubber afirmando que esto de "una ciencia del Derecho Penal alemán" es un asunto "extraño", apuntando que en el Derecho penal lo único científico debe ser tomado del incuestionable estatus de las ciencias sociales y de las ciencias del comportamiento (la economía y, en menor medida, la sociología). Señalando que no puede haber cosa tal como "la única solución para un caso"; por el contrario, hay múltiples decisiones que pueden o no ser correctas, porque hay diferentes formas de analizar y resolver, cuestión que depende de la exposición de los hechos en el juicio. Por ello, le parece "ridículo" que el Derecho Penal alemán autocalifique como "logro científico" el hecho de que pueda haber una la presuntiva "única solución"; todavía más rara la parece la expresión de que ello es de "los grandes logros de las ciencias humanas". No se detiene allí, porque repasa el rol que asume el profesorado en Alemania, su poder e influencia, no sólo en la formación de los profesionales, sino que, también, en la motivación de las decisiones judiciales y en la formación de la ley. Dubber, Markus Dirk, "The Promise of German Criminal Law: A Science of Crime and Punishment", German Law Journal 7, 2005, pp. 1051-1053.

10 Herring, Jonathan, Criminal law, 6 a Edición, Plagrave Macmillan, New York, 2009, p. 37.

11 Dressler, Joshua, Understanding Criminal Law, 2a Edición, Matthew Bender \& Co., New York, 1992 , p. 95 .

12 Singer, Richard; La Fond, John, Criminal Law, 4ª Edición, Wolter Kluwer, Austin-Boston, 2007, p. 53. 
“Una aproximación al sistema de imputación subjetiva en el Derecho Penal anglosajón"

Ahora bien, la acreditación en el proceso de esa relación entre el daño, la voluntad individual y el hecho, a pesar de algunas aparentes excepciones, se estatuye de un modo irrestricto desde el principio de proporcionalidad de la pena cuya manifestación más concreta en este ámbito se traduce en la noción de atribuibilidad personal por el perjuicio social causado (blameworthiness), noción cuya justificación interna se erige esencialmente desde la idea de la retribución como fundamento de la pena. De este modo, la persona es "moralmente culpable" y, por tanto, susceptible de ser penado, sólo si tenía la "real opción" de realizar el hecho y ejercitar con conocimiento la libertad de ejecutar una u otra alternativa ${ }^{13}$. Al respecto, Dressler explica esta idea del modo que sigue:

"Debido al hecho de que la teoría de la retribución asume que los seres humanos poseen libertad y que sus acciones son también libres, es razonable concluir que las personas deberían también ordinariamente responder (por ejemplo, porque son penalmente culpables) por sus actos ilícitos. En tal caso, la intensidad del castigo debe ser proporcional al daño social provocado"14.

Así las cosas, puede verse claramente cómo la idea de culpabilidad, más allá de la discusión sobre su contenido y fundamento en relación con las teorías de la pena, es un principio de validez universal, en cuanto está presente tanto en el sistema de imputación subjetiva del Derecho Penal del common-law como en el Derecho Penal europeo continental ${ }^{15}$. En ambos aparece de un modo significativamente relevante "la creencia en la libertad de la voluntad humana y la consecuente habilidad y el deber de una persona normal a elegir entre el bien

13 Ampliamente, Dressler, Joshua, Understanding, cit. nota n. 11, p. 54. Dubber, Markus Dirk, The Sense of Justice in Penal Law. Empathy in Law and Punishment, New York University Press, New YorkLondon, 2006, pp. 130 y ss.

14 Dressler, Joshua, Understanding, cit. nota n. 11, p. 36.

15 Tanto en los ordenamientos jurídicos herederos de la tradición continental como en los de origen anglosajón se establece como presupuesto indispensable para la habilitación del uso de la pena, entendida como manifestación del recurso estatal más intenso para el control social por implicar la pérdida de la libertad y al mismo tiempo una "estigmatización moral", el hecho de que se acredite en el proceso la culpabilidad de una persona. SINGER; LA FOND, Criminal, cit. nota n. 12, pp. 53 y ss. De esta forma, conforme a Fletcher lo que habilita al ordenamiento jurídico para imponer sanciones penales no es sólo un asunto vinculado a si una persona merece ser encarcelada para la seguridad de la sociedad -con referencias a las tesis de Hart-, sino que la esencia de la imposición de la sanción se encuentra en un juicio de reprochabilidad basado en el merecimiento de pena por un hecho en el cual un sujeto ha elegido libremente vulnerar la norma penal; en consecuencia, la libertad de elección aparece como un requisito entendido como "conocer lo que hay que hacer" o ser "consciente del riesgo" que involucra su realización. FletCHer, George, Basic Concepts of Criminal Law, Oxford University Press, New York-London, 1998, pp. 33 y ss. 
y el mal"16, como los cimientos inmutables e imperecederos sobre los cuales se erige el juicio de reprochabilidad y la medida de la pena.

No sólo la existencia del principio de culpabilidad, sino que la idea de una vinculación del mismo con la seguridad jurídica y la legalidad, entendida como taxatividad, son notas comunes de ambos sistemas jurídico-penales. En el common-law, desde mediados del siglo pasado, imperaba la idea de dotar al mens rea de contenidos específicos, lo que requirió en su momento determinar cuáles habrían de ser los términos concretos que se utilizarían en las leyes penales para conceptualizarlo; es una cuestión que, en cierto modo, surge como una necesidad de limitar la arbitrariedad del juez y sujetarlo al principio de reserva legal. De esta forma, nacieron categorías precisas de imputación subjetiva, pero al mismo tiempo generalizadoras, en respuesta al desorden y a la abundancia de terminologías de la parte especial ${ }^{17}$.

Así las cosas, hasta bien entrado el siglo XX, existía una noción del mens rea, calificada como "tradicional" o "histórica", que consistía en que el hecho era interpretado en su aspecto subjetivo con exclusiva referencia a la mera acreditación de la existencia de la acción (actus reus); en consecuencia, el juicio de culpabilidad se colmaba con el reproche moral sin referencias a nociones vinculadas o concretizadas en específicos estados mentales exigidos por las normas para entender que el hecho es o puede ser atribuible a la persona ${ }^{18}$.

16 Morissete v. United States, 342 U.S. 246 (1952), la cita corresponde al voto del Juez Jackson (la cursiva es nuestra), sitio web: http://www.law.cornell.edu/supremecourt/text/342/246 [visitado el $12 / 04 / 2012]$

17 Al respecto, los redactores del Proyecto de Código Penal Modelo de Estados Unidos (en adelante, CPM) en las actas hicieron referencia al hecho que pudieron encontrar más de setenta y seis términos en todo el ordenamiento jurídico penal referidos al aspecto subjetivo como, por ejemplo, "feloniously", "unlawfully", maliciously", "coruptly", "fraudulently", "spitefully", "willfully", etc. La sistematización y agrupación del contenido conceptual de los diferentes tipos de mens rea, es entendido como el aporte más significativo del referido proyecto al common law. En efecto, en Estados Unidos hay cincuenta y dos códigos penales, además, del Código Federal. Conforme a la Constitución el ius puniendi es una facultad reservada a la autonomía estatal, salvo en relación a cuestiones calificadas como delitos federales (delitos contra el patrimonio de jurisdicción federal exclusiva, los cometidos en bases militares, los perpetrados por funcionarios federales, los de tráfico ilícito de drogas y, en general, los vinculados al crimen organizado). Tanta diversidad legislativa impide, en opinión de Robinson y Dubber hablar de un Derecho Penal de los Estados Unidos. RoBINSON, Paul; Dubber, Markus, "The American Model Code: A Brief Overview", New Criminal Law Review 10:3, 2007, pp. 319-322.

18 La referencia tiene importancia para comprender la evolución del tratamiento del error. En efecto, existía una doble aproximación que dependía de si se trataba de una norma con o sin referencia a algún tipo de estado mental concreto, en particular, si era de aquellos que requerían de la presencia de un dolo específico. Para éstos la regla jurisprudencial del common law consistió en que una vez negada la existencia del estado mental concreto, a través de la prueba allegada al proceso, el error de tipo excluía únicamente el mens rea en sentido restringido. En cambio, para los delitos sin mención a estados mentales específicos, conocidos como general-intent offenses, el error de tipo excluía sólo la 
"Una aproximación al sistema de imputación subjetiva en el Derecho Penal anglosajón"

La evolución del sistema judicial y legal opuso a la visión "tradicional" una estrictamente "estatutaria", según la cual la atribución de culpabilidad conlleva la valoración de la conducta injusta en la situación concreta desvinculada de toda cuestión relativa a la presencia o no de un reproche moral; lo trascendente pasó a ser si conforme a la forma en que ha tenido lugar el hecho en relación con la norma era o no posible imputarle al sujeto, en la situación concreta, un tipo específico de mens rea que, además, esté establecido explícita o implícitamente -por deducción lógico formal- en la descripción legal ${ }^{19}$.

El recurso a esta técnica legislativa tenía por finalidad limitar el arbitrio judicial, simplificando el sistema de imputación y la labor del jurado. A partir de ese momento, comienza a plantearse la exigencia de que todos los delitos contengan una obligatoria mención a un tipo específico de estado mental, tales categorías delictivas son denominadas, actualmente, con el nombre de "specific intent offenses ${ }^{\prime 20}$.

Lo anterior traerá como consecuencia la eliminación progresiva de los delitos de culpabilidad genérica. En efecto, desde mediados del siglo pasado, cada tipo penal describe y señala los estados mentales con los que puede ser cometido. Esta afirmación tiene como excepción los delitos en donde no es necesaria

reprochabilidad moral, esto es, la culpabilidad en sentido amplio. DressLeR, Joshua, Understanding, cit. nota n. 11, p. 129. Ahora bien, es común encontrar en la doctrina la afirmación de que la distinción entre dolo general y específico es totalmente innecesaria e irrelevante y que se presta para confusiones. Sin embargo, a partir de la regla de derecho establecida en la sentencia del caso People v. Hood, se dice que el dolo general es el que está presente en todo delito que requiere de imputación subjetiva, o bien, que implica la prueba de la existencia de mens rea. En este fallo se establece que la defensa de intoxicación puede ser alegada para negar la concurrencia de dolo en delitos específicos, pero no así en delitos generales donde el acusado puede mantener el nivel de comprensión de la realización de un delito simple; lo que ocurre en los supuestos en que se requiere acreditar que ha tenido la intención de ejecutar un delito complejo. People v. Hood, 462 P.2d 370 (1969). Dressler, Joshua, Cases and materials of Criminal Law, $3^{\text {a }}$ Edición, Thomson West, St. Paul, 2003, p. 151. En cambio, el dolo específico es el que está presente sólo en las figuras penales que incluyen la frase "with intent to...(con el dolo de...)", por ejemplo, se afirma que el delito de robo con violencia es un tipo que requiere en su aspecto subjetivo, únicamente de un dolo general, en cambio, el robo con violencia o intimidación cualificado -que en el sistema continental se conoce, generalmente, como un delito complejo-, precisa de un dolo específico, lo que se extiende a otros supuestos como, por ejemplo, al robo con intento de violación. La virtualidad práctica de la distinción está referida a la posibilidad de aumentar la carga de la prueba del órgano persecutor, en favor del acusado. Lo mismo ocurre, entre otros, con el delito de incendio con intento de cobrar un seguro. El delito de incendio, como figura básica, requiere solamente del dolo general (acreditación del mens rea), pero el delito de incendio con intento de cobrar un seguro, es un delito cualificado que necesita, además, de la prueba del aspecto general del mens rea, la acreditación en el proceso del "intento de cobrar un seguro". SINGER; LA FOND, Criminal, cit. nota n. 12, p. 59.

19 Singer; La Fond, Criminal, cit. nota n. 12, p. 54.

20 Sobre esta cuestión y su relación con el principio de culpabilidad. Fletcher, George, Rethinking Criminal Law, $2^{a}$ Edición, Oxford University Press, New York-London, 2000, pp. 398 y ss. 
la prueba de ningún estado mental concreto, los cuales son conocidos como delitos de culpabilidad estricta (strict liability offenses) y que, conforme a la explicación que de su contenido conceptual realiza Fletcher, se corresponden con una técnica legislativa en la cual se prescinde de toda posibilidad de invocar el error sobre los presupuestos fácticos de la norma de valoración y, por ende, son una especie de delitos de responsabilidad objetiva ${ }^{21}$.

Con todo, es posible afirmar que esta distinción entre "lo general" y "lo específico" esconde detrás una noción de reprochabilidad moral que con el tiempo se ha ido modificando hacia la necesaria constatación de un estado mental valorado en términos generalmente objetivos (statutory mens rea). Este asunto, pese a las posibles diferencias de claridad entre los autores, aparece como una cuestión en la que jurisprudencialmente existen reglas bastante definidas, lo que posibilita una uniformidad en la solución de casos concretos, cuestión que adquiere una vital importancia en relación con las eventuales vulneraciones a la seguridad jurídica ${ }^{22}$.

Antes de entrar en el análisis de los tipos específicos de mens rea que se consagran en el Derecho Penal angloamericano resulta fundamental partir de una idea que en el mundo anglosajón se entiende como una premisa básica del Derecho Penal; conforme a ella, éste no es un Derecho asimilable al Derecho de indemnización por daños o perjuicios ("Criminal law is not a tort law") ${ }^{23}$. Lo que se quiere decir, es que mientras en el derecho de daños lo esencial es reparar al demandante inocente si se comprueba la existencia de un perjuicio mediante un estándar objetivo de valoración causal del hecho, que no es otro que el estándar de una persona razonable, el Derecho Penal tiene, en cambio, otras preocupaciones referidas a los fines y funciones que se le asignan a la pena dentro de la sociedad, en particular, su relación con la protección de intereses de relevancia social que se espera sean restablecidos a través del efecto preventivo general ${ }^{24}$. En efecto, tal como ya se ha dicho, la determinación del concreto estado mental con que actuó el sujeto determina también la medida de la sanción penal, su intensidad y, de un modo más general, plantea la pregunta sobre su utilidad en relación con el tratamiento rehabilitador, o bien, la posibilidad de su sustitución total o parcial por una medida de seguridad ${ }^{25}$.

A partir de la normativización de determinados estados mentales como parte integrante de la interpretación, se introduce una importante distinción

21 FletCher, Basic, cit. nota n. 15, p. 398.

22 Singer; La Fond, Criminal, cit. nota n. 12, p.53.

23 Singer; La Fond, Criminal, cit. nota n. 12, p. 54.

24 Fletcher, Basic, cit. nota n. 15, p. 78.

25 Dubber, Markus Dirk, The Sense, cit. nota n. 13, p. 128. 
“Una aproximación al sistema de imputación subjetiva en el Derecho Penal anglosajón"

entre, por una parte, el concepto de delito como injusto (wrongdoing) y, por la otra, la atribución o imputación subjetiva de ese hecho a una persona en particular ${ }^{26}$. Así, de vuelta a los fines y funciones del Derecho Penal, surge la necesidad de estudiar las cuestiones vinculadas a la asunción por parte del autor de concretos déficits de motivación normativa y, al mismo tiempo, de intensidades de "determinación de la libertad", como de "conocimiento" de la norma en la situación concreta, asunto cuya interrelación permite constatar diferentes niveles de atribución de responsabilidad por el hecho ${ }^{27}$. Al desarrollo de este asunto dedicaremos las páginas que siguen.

\section{EL MENS REA EN EL COMMON-LAW Y el Model Penal Code}

En el ámbito anglosajón se suele afirmar que uno de los aportes más significativos al Derecho Penal en el plano de la imputación subjetiva lo ha hecho el Proyecto de Código Penal Modelo de Estados Unidos de 1962 (en adelante, $(\mathrm{CPM})^{28}$. En efecto, la doctrina sostiene que su texto contribuyó a la eliminación de los delitos de culpabilidad genérica, como también, propició un cúmulo de sucesivas reformas legales que intentaban indicar cuáles habían de ser los elementos subjetivos que debían tomarse en consideración para el análisis de

26 Ampliamente, FletCHer, Rethinking, cit. nota n. 20, pp. 455 y ss. Se trata de una distinción con un fuerte arraigo en la filosofía de Kant, en especial, en la distinción entre "mérito" y "demérito". Sobre esto, por todos, HruschKA, Joachim, "Imputation", Brigham University Law Review 669, 1986, pp. 677 y ss. Para una aproximación a ambos sistemas jurídicos basada en esta perspectiva de Hruschka que distingue entre reglas de comportamiento y reglas de imputación desde la teoría de las normas, indicando, a partir de la concepción de Moore que es posible una aproximación conceptual basada en la constatación de que en la mayoría de los delitos se exige que la acusación demuestre la existencia de un estado mental que coincida con el expresado en la norma de valoración, entendiendo, desde ese lugar, que es factible distinguir entre una culpabilidad prima facie caracterizada por la constatación de los estados mentales exigidos por la respectiva norma y una culpabilidad definitiva que se colma con la ausencia de supuestos de exclusión de imputación personal del hecho, expresados en la existencia de una norma permisiva, o bien, como consecuencia de la presencia de hechos que excluyen la necesidad de pena, ampliamente, MAÑALICH RAFFO, Juan Pablo, "Bases para una teoría comparativa del hecho punible", Revista Jurídica de la Universidad de Puerto Rico 75:2, 2006, pp. 568 y ss.

27 Para esta distinción, HART, Herbet, "Legal Responsibility and Excuses", Punishment and Responsa-

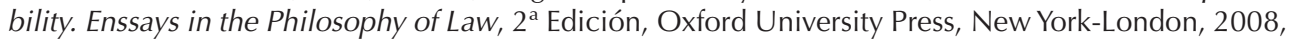
pp. 33 y ss.

${ }^{28}$ Véase, supra nota n. 17 y 18. El CPM fue redactado por el American Law Institute. El ámbito de su influencia puede ser medido incluso en términos cuantitativos, ya que desde su publicación los cincuenta y dos códigos penales existentes en los Estados Unidos, fueron modificándose adoptando de modo progresivo la mayoría de las ideas contenidas en el proyecto. Con todo, pese a algunas excepciones, como la idea del CPM de castigar con igual pena la tentativa y la consumación dolosa de homicidio simple, el aporte más relevante es el haber reducido la imputación subjetiva a cuatro categorías genéricas. Robinson, Paul; Dubber, Markus, "The American", cit. nota n. 17, pp. , pp. 319-322 
los estatutos o disposiciones legales ${ }^{29}$. Pero, tal vez sus disposiciones no habrían alcanzado tanta influencia si no fuese, precisamente, por la consagración de un modelo legal de atribución de responsabilidad penal que, en el plano subjetivo, se basa en la necesaria acreditación en el proceso de alguno de los cuatro niveles de mens rea que, al mismo tiempo, permiten graduar la intensidad de la pena en orden decreciente. En este modelo la desconsideración o recklessness constituye el nivel de atribución de imputación subjetiva por defecto, es decir, la forma básica dentro de las categorías de imputación subjetiva.

Junto con lo anterior, el CPM indica los criterios de análisis jurídico-normativo que posibilitan dilucidar, en un plano interpretativo, qué palabras contempladas en la norma penal pueden ser entendidas como elementos simples o genéricos de la descripción y cuál o cuáles de ellas constituyen elementos materiales del delito ${ }^{\prime 30}$. Esta distinción tiene importancia porque únicamente estos últimos son considerados para efectos de la imputación subjetiva.

En efecto, los elementos simples del delito son cuestiones anexas al juicio de valoración del hecho, en concreto, se refieren a asuntos de competencia jurisdiccional, o bien, a otras cuestiones de orden procesal ${ }^{31}$. En cambio, los denominados elementos materiales del delito son los que sirven para la realización del juicio de valoración, por cuanto se refieren a la acción y sus circunstancias concretas, al resultado y, especialmente, a la valoración de los estados mentales. Al respecto, el CPM establece en la sección 2.02 (2) los referidos cuatro niveles de imputación subjetiva -que se conocen como tipos de culpabilidad en sentido restringido-, que son los siguientes: a) Purposely; b) Knowingly; c) Recklessly; d) Negligently ${ }^{32}$.

29 Por "estatuto" se entiende, conforme a la sección 1.13 (1) del CPM, tanto la Constitución como una ley local u ordinaria de una subdivisión política estatal. Model Penal Code, Official Draft 1962, American Law Institute, en: DressLer, Joshua, Cases and materials of Criminal Law, $3^{\text {a }}$ Edición, Thomson West, St. Paul, 2003, p. 992.

30 Lo anterior, se deduce de los numerales (9) y (10) de la sección 1.13 donde se indica lo siguiente: "(9) 'element of an offense' means (i) such conduct for (ii) such attendant circumstance or (iii) such a result of conduct as (a) is included in the description of the forbidden conduct in the definition of the offense; or (b) establishes the required kind of culpability; or (c) negatives and excuse or justification for such conduct; or (d) negatives a defense under the statute of limitations; or (e) establishes jurisdiction or venue; (10) 'material element of an offense' means an element that does not relate exclusively to the statute of limitations, jurisdiction, venue or to any other matter similarly unconnected with (i) the harm ore vile, incident to conduct, sought to be prevented by the law defining the offense, or (ii) the existence of a justification or excuse for such conduct". MOdel PeNAL CODE, cit. nota n. 29, p. 992.

31 Singer; LA Fond, Criminal, cit. nota n. 12, pp. 75-76.

32 Según Fletcher el CPM reconocería una concepción mixta de la culpabilidad, a partir de esta distinción entre propósito, conocimiento, desconsideración e imprudencia. Las dos primeras categorías se basan en un "objeto consciente" y en la "conciencia del riesgo", y serían coincidentes con la teoría psicológica de la culpabilidad. En cambio, las ideas de desconsideración e imprudencia, apuntan a la teoría normativa de la culpabilidad, FleTCHeR, Gramática, cit. nota n. 1, p. 428. 
"Una aproximación al sistema de imputación subjetiva en el Derecho Penal anglosajón"

A continuación, analizaremos cada uno de ellos, pero desde las nociones conceptuales o terminológicas del common-law, incorporando las particularidades del Derecho Penal de los Estados Unidos, en la medida en que sea necesario para destacar matices o diferencias.

\section{El DOlO EN SENTIDO RESTRINGIDO (INTENT)}

Desde una aproximación general, se afirma que esta categoría es asimilable a lo que en el Derecho continental se conoce como dolo directo, en cuanto se corresponde con la idea de propósito o intención de realización del tipo objetivo $^{33}$. Tal aproximación podría implicar subsumir esta terminología en la tesis dominante de la dogmática penal continental conforme a la cual se define el dolo como "el conocimiento y voluntad de realización de los elementos descriptivos y normativos del tipo" ${ }^{\prime \prime 3}$. Ahora bien, sucede que, en realidad, en el Derecho

33 Bohlander, Michael, Principles of German Criminal Law, Vol. 2, Hart Publishing, Oxford, 2009, p. 63. TAYLOR, Greg, "Concepts of intention in German Criminal Law", Oxford Journal of Legal Studies 24:1, 2004, p. 102. Fletcher, Rethinking, cit. nota n. 20, p. 439 y ss. Mañalich, "Bases", cit. nota n. 26, p. 622.

34 Debe hacerse una obligatoria mención a la tesis del conocimiento como exclusivo contenido del dolo. Ésta pretende establecer la delimitación entre el dolo y la imprudencia, únicamente sobre la base de la existencia del binomio conocimiento/desconocimiento. JAKOBS, Günther, Derecho Penal. Parte General: Fundamentos y teoría de la imputación, Joaquín Cuello Contreras y José Luis Serrano

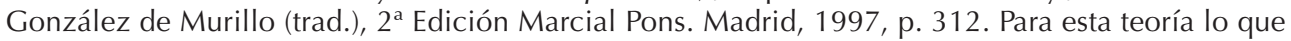
determina la presencia de un tipo de acción u omisión dolosa es la actuación con conocimiento de los elementos que integran el tipo penal, prescindiendo de toda consideración de carácter volitivo. Así, lo que un sujeto "espere", "confíe" o "desee" carece de relevancia cuando se prueba que sabe que está realizando la conducta típica o que ha previsto el resultado. Vid., Zugaldía EsPINAR, José; Pérez Alonso, Esteban, Derecho Penal. Parte General, $2^{a}$ Edición, Tirant Lo Blanch, Valencia, 2004, p. 491. De este modo, se considera dolosa la realización de un delito en el caso en que el agente ha sido consciente de la realización de los elementos objetivos del tipo y, en el caso de los delitos de resultado, habrá dolo si al momento de realizar la conducta se ha previsto la lesión como manifestación causal de la misma. En tal sentido, con algunos matices se afirma que el dolo no depende estructuralmente de los fenómenos internos o psicológicos que el sujeto padezca al momento de la realización de la conducta, sino que únicamente aparece condicionado por la adscripción a un proceso de imputación a partir de los fines de la pena y en este lugar el dolo es esencialmente "conocimiento actual y correcto de la situación y del riesgo para el bien jurídico". Bustos Ramírez, Juan; Hormazabál Malarée, Hernán, Lecciones de Derecho Penal, Parte General, $2^{a}$ Edición, Trotta, Madrid, 2006, p. 208. Esta teoría se encuadra dentro de lo que Ragués denomina las tesis de "decisión contra el bien jurídico", cuyo problema principal sería el determinar cuántos indicios deben concurrir para que pueda afirmarse la presencia de dolo o qué sucede en el caso de que éstos se contradicen, por ello, la fórmula pareciera ser demasiado "vaga", ya que de algún modo requiere la presencia de un elemento volitivo. Ragués I Vallès, Ramón, El dolo y su prueba en el proceso penal, Universidad Externado de Colombia, Bogotá, 2002, p. 115. Ragués I Vallès, Ramón, "Consideraciones sobre la prueba del dolo", Revista de Estudios de la Justicia 4, 2004, p. 15. Aunque no existe consenso sobre qué debe entenderse por el conocimiento de la lesión al bien jurídico, ni tampoco es posible afirmar que algunos de los partidarios de la teoría abandonen derechamente el requisito de la voluntad; lo que sucede es que la decisión contra el bien jurídico sirve para caracterizar al dolo y, también, es su elemento volitivo, pero normativizado, esto es, quien actúa dolosamente lo hace regido "por su 
angloamericano se acostumbra a indicar que no existe una fórmula general reductiva; no hay una suerte de máxima aforística conceptual y de aplicación genérica que pretenda definir y, por ende, decidir todos los casos en que concurre el dolo directo si, por ello, podríamos traducir el término intent. Es más, tampoco hay definiciones generalizadoras respecto de las restantes categorías de estados mentales asociados al mens rea, sin perjuicio de la constatación de esfuerzos conceptuales tanto en el CPM, como en la doctrina y jurisprudencia del common-law.

voluntad", pero, además, adopta una decisión contraria al bien jurídico con mayores repercusiones que las previstas para el que actúa de forma imprudente. La teoría cognitiva como decisión en contra del bien jurídico se presenta como una alternativa a la excesiva normativización del dolo. Según una variante de la misma, hay dolo en la existencia de una situación de peligro inminente y concreto de lesión del bien jurídico, unido a la aprehensión correcta de esta situación en toda su extensión y significado. Díaz Pita, María del Mar, "La presunta inexistencia del elemento volitivo en el dolo y su imposibilidad de normativización", Revista Penal 17, 2006, p. 68. Cfr. Roxın, Claus, Derecho Penal. Parte General, t. I. Diego Luzón Peña; Miguel García Conlledo, et al. (trads.), Civitas, Madrid, 1997, p. 419. Ahora bien, las tesis cognitivas normativizadas (o teorías del conocimiento o de la representación), postulan que el dolo "ya no es conocimiento y voluntad, sino únicamente conocimiento", así se señala que es suficiente que el sujeto haya obrado con conocimiento del riesgo concreto de producción del resultado (delitos de resultado), o bien, es suficiente que sepa que su comportamiento concurren los elementos que integran el tipo objetivo penal, en consecuencia, aquello que excluye el dolo sólo pasa a ser un error y no algo que se determine por la inexistencia de voluntad (delitos de mera actividad). Lo importante, es que "el sujeto actúe pese a atribuir a su conducta la concreta capacidad de realizar el tipo penal", o bien, como señala Feijóo "el injusto doloso se caracteriza porque una persona toma la decisión de realizar un hecho a pesar de conocer (abarcar intelectualmente) todas las circunstancias fácticas que van a convertir ese hecho en un hecho típico". FEıJóo SÁnCHEZ, Bernardo, "La distinción entre dolo e imprudencia en los delitos de resultado lesivo. Sobre la normativización del dolo", Cuadernos de Política Criminal 65, 1998, pp. 277 y ss. Ampliamente, sobre este punto, Laurenzo Copello, Patricia, Dolo y conocimiento, Tirant lo Blanch, Valencia, 1999, p. 189 y ss. Así también, por ejemplo, Silva señala que "en lo relativo al contenido, debe optarse por un contenido cognoscitivo. La voluntariedad no es elemento del dolo, sino un elemento de la acción". Silva SÁnchez, Jesús María, Aproximación al Derecho Penal contemporáneo, Bosch Editor, Barcelona, 1992, pp. 401 y ss. Otra tesis, como conciencia de la antijuridicidad, pero también desde la tesis del conocimiento. Mir Puig, Santiago, Derecho Penal. Parte General, $8^{a}$ ed. Reppertor, Barcelona, 2008, p. 265. Por la tesis de la voluntad en sentido clásico, entendiendo que el dolo es además un dolus malus, como conciencia de la antijuridicidad del hecho. CoBo Del Rosal, Manuel; Vives Antón, Tomás Salvador, Derecho Penal. Parte General, 5ª Edición, Tirant lo Blanch, Valencia, 1999, p. 625. Desde la concepción del finalismo ortodoxo, entendiéndolo como "conocimiento y voluntad". Cerezo Mir, José, Curso de Derecho Penal español, t. II, 6a Edición, Tecnos, Madrid, 1998, p. 144. Por la postura del dolo como conocimiento y voluntad, pero entendida ésta como un compromiso con la acción (voluntad normativizada). Orts Berenguer, Enrique; GonzÁlez Cussac, José Luis, Compendio de Derecho Penal Parte General, 3 ${ }^{a}$ Edición, Tirant lo Blanch, Valencia, 2011, p. 292. Por la tesis de la doble posición del dolo, esto es, como elemento constitutivo del injusto típico y, también, como un elemento autónomo de la culpabilidad. MoriLLas Cuevas, Lorenzo, Derecho Penal. Parte General. t. II. Vol. 1, Dykinson, Madrid, 2008, pp. 176-177. Una aproximación en inglés, desde el Derecho Penal español. Gorrız Royo, Elena, Institutions of Criminal law. General Part, Universitat de València, Valencia, 2012, p. 91. 
“Una aproximación al sistema de imputación subjetiva en el Derecho Penal anglosajón”

De esta forma, lo verdaderamente trascendente pasa a ser la valoración de los términos utilizados por el legislador en la descripción del contenido normativo del respectivo estatuto, distinguiendo aquello que resulta relevante para la averiguación de la concurrencia fáctica de los presupuestos de imputación subjetiva previstos en éste, vinculando la acción realizada con la prueba de las circunstancias concurrentes que rodean el hecho, deduciendo desde ese lugar el respectivo estado mental previsto en cada delito.

El CPM consagra esta categoría de dolo agrupándola en la denominación del actuar con "purposely"35 o de propósito, que equivale al término "intent" del common-law ${ }^{36}$. Para afirmar su concurrencia debe ser posible establecer una vinculación en perspectiva, partiendo desde los elementos materiales de la definición estatutaria hacia la naturaleza de la conducta desplegada o el resultado, teniendo en cuenta la naturaleza del objeto empleado en la acción y, en especial, si puede afirmarse que, al momento de llevar a cabo la conducta, su autor tuvo en cuenta, esperaba o creía que los hechos concomitantes eran ciertos y constituían la forma precisa de realización del resultado ${ }^{37}$. Sucede que si bien resulta acertado elucubrar una virtual coincidencia entre el intent y el dolo directo de nuestro sistema, como anota Bernal del Castillo ${ }^{38}$ tal idea no implica equivalencia exacta.

Pese a la anterior afirmación, la teoría del dolo elaborada por Vives Antón ${ }^{39}$ en el Derecho Penal español coincide, hasta donde puedo ver, con la terminología y el alcance conceptual que se le otorga al dolo directo en el Derecho anglosajón. En efecto, Vives pone de manifiesto que una vez constatado el primer nivel de imputación denominado pretensión de relevancia (que coincide con el actus reus), es necesario indagar en el examen de la pretensión de validez que se relaciona con la antijuridicidad forma ${ }^{40}$ (imputar al sujeto el comportamiento

37 "Section 2.02. (2) (a) Purposely. A person acts purposely with respect to a material element of an offense when: (i) If the element involves the nature of his conduct or a result thereof, it is his conscious object to engage in conduct of that nature or to cause such a result; and, (ii) If the element involves the attendant circumstances, he is aware of the existence of such circumstances, he is aware of the existence of such circumstances or he believes or hopes that they exist". Model Penal Code, cit. nota n. 29 , p. 994.

38 Singer; La Fond, Criminal, cit. nota n. 12, p. 77.

39 Sección 2.02 (2) (a) (i) y (ii), del CPM. Model Penal Code, cit. nota n. 29, pp. 993-995. Más adelante, haremos mención al denominado dolo de transferencia, el cual es considerado un problema vinculado con la causalidad y no se regula en esta parte, sino que en la sección 2.03 (2), del CPM.

38 Bernal del Castillo, Derecho Penal, cit. nota n. 4, p. 134.

39 Vives Antón, Tomás Salvador, Fundamentos del sistema penal. Acción significativa y derechos cons-

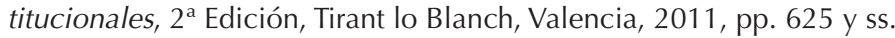

40 Martínez-Buján Pérez, Carlos, "El concepto `significativo’ de dolo: un concepto volitivo normativo", en Problemas actuales del Derecho Penal y de la Criminología. Estudios penales en memoria de la profesora María del Mar Díaz Pita, Tirant lo Blanch, Valencia, 2008, pp. 324 y ss. 
prohibido como realización del tipo, en el plano de la capacidad de evitación voluntaria de la conducta, que se corresponde con la idea anglosajona de culpabilidad prima facie en cuanto ella reclama la acreditación de determinados estados mentales, aquí el dolo); es decir, se debe valorar la infracción de la norma de prohibición o de mandato, cuestión que implica constatar si en el contexto de interrelación subjetiva en que ha tenido lugar la acción, ella podía ser interpretada como expresión comunicativa de un sentido determinado, en este caso, como manifestación exteriorizada de intención ajustada a las exigencias del ordenamiento jurídico. Este requerimiento de intención subjetiva permite atribuirle un compromiso al sujeto con la acción realizada ${ }^{41}$.

El dolo es, entonces, un compromiso con la acción ${ }^{42}$, con independencia de ese "algo" que está detrás (lo interno o lo psicológico, cuestión que tampoco interesa al Derecho anglosajón); el dolo no está fuera de la acción porque pertenece a la interpretación del sentido de la misma, conforme al contexto de comunicación en que ha tenido lugar ( $y$, tal como en el Derecho anglosajón, en Vives esa interpretación de sentido depende exclusivamente de lo que se acredite o se pruebe en el proceso, o si se quiere, es algo que se entrega al sentido que del "saber" o "conocer" entienda el jurado; esto es, el carácter público del saber en palabras de Vives) y, finalmente, ese "creer que algo es cierto" que forma parte del dolo en el Derecho Penal anglosajón no es otra cosa que la acción misma; no es "algo distinto de ella" ${ }^{43}$.

En efecto, en el common-law se sostiene derechamente que lo verdaderamente determinante es que, tanto el jurado como el juez, conforme a las circunstancias concretas del caso, la prueba alojada al proceso y la descripción que se hace del aspecto subjetivo del delito en la ley, puedan afirmar, más allá de toda duda razonable, que el defendido actuó con un respectivo estadio de imputación subjetiva, en el sentido de un devenir determinante para la

\footnotetext{
${ }^{41}$ Vives Antón, Tomás Salvador, "Reexamen del dolo", en Problemas actuales del Derecho Penal y de la Criminología. Estudios penales en memoria de la profesora María del Mar Díaz Pita, Tirant lo Blanch, Valencia, 2008, pp. 369 y ss.

42 Ampliamente, González Cussac, José Luis, "Dolus in re ipsa", en Carbonell Mateu, Juan Carlos; González Cussac, José Luis, et al. (dirs.); Cuerda Arnau, María Luisa (coord.), Constitución, derechos fundamentales y sistema penal (semblanzas y estudios con motivo del setenta aniversario del profesor Tomás Salvador Vives Antón), Tirant lo Blanch, Valencia, 2009, pp. 818 y ss.

${ }^{43}$ Este punto de vista permitiría superar la objeción que realiza Taylor quien sostiene que en el Derecho continental se manejan ideas sobre "voluntad" o "conocimiento" de espaldas a la filosofía del lenguaje, como si el Derecho Penal alemán se encontrase habilitado para crear categorías con independencia de lo que postule, por ejemplo, la psiquiatría o la psicología. Afirma derechamente que le parece demasiado "simplista" que todo estado mental pueda ser taxonómicamente clasificado de forma tan rígida, intentando encajar en conceptos resumidos cuestiones que dependen del sentido que pueda atribuírsele a un acto en un caso concreto. TAYLOR, "Concepts", cit. nota n. 33, pp. 122-123.
} 
realización del hecho, siendo así la única posibilidad de afirmar la responsabilidad penal. Con todo, esta interrelación entre el respectivo estado mental previsto en norma y la valoración de la prueba, es una cuestión perteneciente exclusivamente al mens rea. Así, de modo contrario a lo que podría deducirse a priori, en esta primera aproximación no existe vinculación valorativa con la probabilidad de que el resultado o el peligro puedan tener lugar, porque tal cuestión es un asunto relativo a la eventual coincidencia entre el plano subjetivo con el ámbito objetivo de la imputación, esto es, a la correlación entre actus reus y mens rea.

Así las cosas, el estado mental de intent se tiene por acreditado con independencia de la valoración de la idoneidad de los medios empleados para dar principio de ejecución al hecho. De esta forma, tal como ocurre en la tesis finalista de la acción, el dolo existe aunque el medio sea absolutamente inidóneo para producir el resultado, puesto que lo único que se exige para tener por acreditado el dolo, por ejemplo, en el delito de homicidio, es que el sujeto realice una acción con el propósito o intención de matar, si el medio que ha seleccionado para llevarlo a cabo o ejecutar el hecho es inidóneo absoluta o relativamente en relación con el riesgo provocado no resulta ser una cuestión relevante. En el common-law, por consiguiente, quien ha intentado dolosamente un homicidio y la muerte ocurre, será responsable aunque el resultado sea poco probable o incluso artificioso en relación a la idoneidad de los medios elegidos para realizar la acción ${ }^{44}$.

Ahora bien, tal como ocurre en el Derecho continental es posible distinguir en este punto supuestos en los cuales el autor actúa con dolo, pero éste no abarca el resultado, o bien, éste ocurre de un modo totalmente diferente al propósito del autor. Es cierto que tales situaciones pueden desglosarse en numerosas combinaciones de posibilidades. Sin embargo, si se asume como punto de referencia inicial un supuesto hipotético en que podría existir absoluta correspondencia de atribución de sentido de la acción como sería el caso en que $A$ apunta a la cabeza de $B$ con un revólver y le dispara a corta distancia produciéndose la muerte, resulta posible agrupar preliminarmente tales casos en al menos cuatro hipótesis que derivan de la progresión del defecto de correlación entre el dolo y el resultado: i) $A$ actuó con el propósito de disparar a un árbol, porque se ha probado que ignoraba que $B$ se hallaba en su interior escondido, $y$, por ende, ha faltado "el otro" exigido por la respectiva descripción legal del delito de homicidio; ii) $A$ no tenía la intención de disparar a $B$, porque conforme a la prueba allegada al proceso se ha acreditado que jaló del gatillo pensando que el arma se hallaba descargada; iii) A dispara el arma con la intención de matar

${ }^{44}$ Singer; LA Fond, Criminal, cit. nota n. 12, p. 56. 
a $B$, pero ha resultado la muerte de $C$; iv) $A$ dispara el arma con la intención de herir a $B$, pero resulta la muerte.

Las hipótesis i) y ii) en el Derecho angloamericano son supuestos que se relacionan con lo que se conoce como mistake of fact (error de hecho) cuya naturaleza jurídico-penal es la de constituir una excuses ${ }^{45}$ que excluye, al menos en principio, la posibilidad de imputación subjetiva y que puede ser definida como un supuesto en el cual, pese a que se ha provocado un daño socialmente proscrito por las normas, es posible inferir, a través de la conducta desplegada, que el autor ha incurrido en una falsa representación de la concurrencia de los presupuestos fácticos de la imputación contemplados en la norma ${ }^{46}$.

En este orden de consideraciones, es necesario realizar algunas precisiones relativas a una distinción sutil, pero trascendente para los efectos de una aproximación descriptiva, según la cual no es lo mismo la ignorancia de los hechos concretos que el error sobre la concurrencia fáctica de los hechos. La ignorancia implica una total falta de conocimiento es "un actuar con la mente en blanco en consideración a los hechos", mientras que el error supone una errónea creencia equivocada de la realidad. Según explica Dressler la diferencia no tiene efectos prácticos apreciables en el Derecho angloamericano ${ }^{47}$, lo que hace que el supuesto de imprudencia inconsciente no constituya en el common-law una categoría especial de imputación, sino que un supuesto asi-

45 Las excuses (sencillamente, excusas) constituyen una categoría de defensas legales que pueden ser invocadas por el acusado para excluir su culpabilidad. A través de ellas se reclama alguna condición o circunstancia personal concurrente al momento de la realización de la acción que inhabilita el reproche por parte de la ley penal. Ahora bien, el hecho continúa siendo contrario a la norma penal (lo injusto no desaparece), pero admite la posibilidad de exclusión de responsabilidad en virtud de circunstancias especiales de inexigibilidad o condiciones personales inherentes al sujeto que hacen sugerir que no le es atribuible el hecho en relación con la capacidad de acción. Se diferencia del error de derecho (mistake of law) en que este es una mala interpretación de la ley que resulta relevante para la situación ocurrida; la ignorancia de la ley no constituye una excusa en el Derecho anglosajón. Sin embargo, la ignorancia de la ley o el error de derecho puede constituir una defensa en los casos en que el delito requiere de un tipo específico de dolo, o bien, cuando el error de derecho niega el mens rea requerido por la norma. A este respecto puede verse el caso RATZLAF v. United State, (92-1196), 510 U.S. 135 (1994), sitio web: http://www.law.cornell.edu/supct/html/92-1196.ZO.html- [visitado el 22/04/2012]. Dentro de esta categoría se incluyen otros supuestos de inexigibilidad, como la defensa afirmativa de duress en el que el sujeto realiza una conducta coaccionado para su realización, debido a la existencia de una amenaza o de una fuerza ilegítima contra su persona o un tercero. También, se incluyen aquí los supuestos de intoxicación por introducción de una sustancia en el cuerpo sin el consentimiento del acusado, que en el caso de ser voluntaria sólo excluye el dolo directo en aquellas figuras penales en las que se pide expresamente. Además, hay otras defensas como la de minoría de edad, el entrapment y el syndrome-based defense enhancements, que no es del caso desarrollar aquí por exceder los límites de esta investigación. Schamalleger, Criminal, cit. nota n. 2, pp. 195 y ss.

46 Dressler, Joshua, Understanding, cit. nota n. 11, p. 127.

47 Dressler, Joshua, Understanding, cit. nota n. 11, p.127. 
milable valorativamente al mistake of facts; y, en consecuencia, la idea básica es que quien actúa en estos supuestos tiene, tal como su nombre lo indica, una errada percepción de la realidad que, al no estar originada en una causa de demencia, intoxicación u otros factores especiales, permite exculpar al autor del daño causado ${ }^{48}$.

El fundamento para excluir la culpabilidad del autor que ha actuado con error de hecho no es otro que la imposibilidad de inferir la libertad de la voluntad en sentido pleno. Aunque se reconoce que el uso del término "voluntario" es algo controvertible debido a las numerosas acepciones que posee en el Derecho Penal anglosajón, acá se utiliza en el sentido de que el sujeto realiza un hecho sin tener ningún tipo de oportunidad de evitar un daño que podría no haberse producido de saber lo que estaba haciendo; por ende, más que con el aspecto "volitivo" (capacidad de control de la conducta) se conecta con el aspecto "cognitivo" (estar consciente de lo que se realiza) ${ }^{49}$.

De esta manera, no podría afirmarse que quien ha actuado en los supuestos i) y ii) haya obrado con intent, puesto que faltaría el aspecto cognitivo del mismo, esto es, conocer los riesgos que implica la realización del hecho. En cuanto al mens rea, el mistake of facts elimina tanto la culpabilidad en sentido amplio entendida como ausencia de la libertad de la voluntad y, por ende, como incapacidad social de reprochabilidad moral por el daño causado, como también, la culpabilidad en sentido restringido, esto es, aquella disposición mental contenida en el respectivo estatuto normativo. A esta afirmación hacen excepción los delitos de responsabilidad objetiva en los cuales no es necesaria la acreditación de ningún tipo de mens rea y, por ende, conforme a su propia naturaleza impiden la alegación de la excusa de error sobre los hechos.

Acá hay otra diferencia con el Derecho continental, en particular en un caso que es citado como un supuesto ícono de error de tipo esencial invencible en que incurre el sujeto que actúa en representación errónea sobre la edad de la persona con quien realiza un acto sexual consentido. En el Derecho angloamericano, por regla general, el delito de violación cometido contra menores de edad no admite la alegación por parte de la defensa de que conforme a las circunstancias concretas que rodean el hecho el sujeto incurrió en un error sobre la capacidad de consentimiento sexual, ${ }^{50}$ incluso aunque aquello pueda resultar una cuestión razonable debido a la apariencia física del sujeto pasivo, o bien, de acuerdo a la forma en que tuvieron lugar los hechos. De este modo, puede verse que no todos los supuestos de la hipótesis $i$ ) admiten en ambos sistemas

\footnotetext{
48 Schamalleger, Criminal, cit. nota n. 2, p. 206.

DressleR, Joshua, Understanding, cit. nota n. 11, p. 128.

DressLer, Joshua, Understanding, cit. nota n. 11, p. 130.
} 
un idéntico tratamiento jurídico, al menos no para todos los casos. En el Derecho angloamericano, la cuestión sobre la racionabilidad del error se decide en el caso conforme a la estructura de cada delito. Así, por ejemplo, a partir de la reforma que ha tenido lugar en Inglaterra en el año 2003, los delitos sexuales cometidos contra menores han pasado a estructurarse básicamente como delitos de responsabilidad objetiva (strict liability). Pero, fuera de esas diferencias de estructura típica interna y del hecho que no se considere en el Derecho continental al error como una defensa -en el sentido anglosajón del término-, sino como un supuesto de exclusión del dolo, lo trascendente es, como anota Bohlander ${ }^{51}$, que en el Derecho anglosajón el error sobre los presupuestos fácticos de la concurrencia del mens rea, en su modalidad de intent, es una cuestión que se reduce a la prueba del proceso y no a fórmulas generalizadoras. Así, en relación con los delitos contra la libertad sexual cometidos contra menores de edad, la cuestión ha sido reseñada por Lord Hailsham al sostener, con ocasión del fallo del caso Morgan ${ }^{52}$, del siguiente modo:

"Una vez que hemos aceptado que el contenido de la prohibición del delito de violación es la realización de un acto sexual no consentido y que el estado mental exigido para afirmar la culpabilidad es el dolo; es una cuestión de lógica formal inexorable que no hay espacio para la valoración razonable y sincera del error sobre los hechos. O bien, la fiscalía prueba que el acusado actuó con el dolo requerido por la norma o no lo hace. En el primer caso, afirmará la culpabilidad y en el segundo, sencillamente, no" ${ }^{\prime \prime 3}$.

En cuanto al supuesto ii), las posibles soluciones en el Derecho continental irían por afirmar que se trata de un caso de error de tipo esencial vencible que excluye el dolo y deja subsistente la culpa; y también, sería factible aseverar derechamente la imputación a título de culpa inconsciente, debido a que el sujeto ha obrado con total inadvertencia en relación con un peligro concreto que ni siquiera se interesó en constatar. Ambas tesis estimamos que serían correctas. A su turno, en el Derecho anglosajón sucede algo, en principio, bastante similar; el caso sería tratado como un error que recae sobre los presupuestos fácticos de la realización del actus reus y la consecuencia más aceptada es la de imputar por defecto negligencia. Ahora bien, tal como en el Derecho continental la medida para la exclusión de la imputación subjetiva queda sujeta a un baremo que

51 Bohlander, Principles, cit. nota n. 33, p. 71

${ }^{52}$ Regina v. Morgan, House of Lords, A. C. 182 (1976), en KAdISH, Sanford; Schulhofer, Stephen; PAulsen, Monrad, Criminal law and its processes: cases and materials, 4ª Edición, Little Brown \& Co., Boston, 1983, pp. 286-292.

53 Cfr. Bohlander, Principles, cit. nota n. 33, p. 71. 
apela a la racionabilidad o irracionabilidad de la representación de la existencia de los presupuestos fácticos de la imputación penal en el hecho concreto en que haya tenido lugar. Así las cosas, se dice que la equivocada interpretación de los hechos por parte del sujeto, excluye la culpabilidad a menos que pueda afirmarse un merecimiento de pena por haber incurrido en el error. Ello ocurre, por ejemplo, en los casos en que una persona razonable con un mínimo de cuidado podría haber evitado incurrir en el error; en tales supuestos, como se indicó, lo que ocurrirá es que el sujeto será imputado a título de negligencia. Con todo, ello tampoco será posible en todos los supuestos, al menos no penalmente, porque en el Derecho angloamericano se requiere para ello que se trate de una negligencia "grosera", esto es, el realizar una acción que implique un riesgo injustificado cualitativamente más grave del que podría resultar de una mera responsabilidad civil ${ }^{54}$.

En esta misma línea de apreciaciones, en el Derecho continental los supuestos comprendidos en los casos iii) y iv) siguen siendo abordados como casos de error de tipo. En efecto, podría indicarse, por un lado, que el supuesto iii) es un caso de error en el golpe y, por el otro, que la hipótesis iv) es una cuestión referida a los denominados delitos preterintencionales. No ocurre lo mismo en el Derecho angloamericano, donde ambos casos pasan a constituir modalidades específicas de imputación subjetiva. En efecto, el caso iii) se estatuye como una modalidad independiente de dolo, conocido como transferred intent (dolo de transferencia); y el caso iv) es abordado como otro supuesto diferenciable de los anteriores al cual se le ha dado el nombre de oblique intent (dolo de oblicuidad). A ambos tipos de dolo dedicaremos los apartados que siguen.

\section{El DOLO DE TRANSFERENCIA (TRANSFERRED INTENT)}

En el Derecho anglosajón es común afirmar que esta institución es propia del Derecho de daños y que se ha transpuesto al Derecho Penal a raíz de la influencia de la jurisprudencia como fuente del Derecho, resumiéndose en la curiosa afirmación que "la intención sigue la bala"55. Ahora bien, aquí la responsabilidad pone su acento exclusivamente en los resultados que pueden ser vistos en la misma línea de progresión de un actus reus llevado a cabo con dolo. Se trata de una doctrina que se aplica en el common-law desde el siglo XVI, adoptada también por el Derecho Penal de Estados Unidos, donde conforme explica Dressler ${ }^{56}$ es invocada comúnmente para la solución de los

54 Dressler, Joshua, Understanding, cit. nota n. 11, p. 132.

55 Singer; La Fond, Criminal, cit. nota n. 12, p.57.

56 Dressler, Cases, cit. nota n. 18, pp.149-150. 
casos en que una persona intenta matar a otra, pero accidentalmente el resultado lesivo previsto se realiza en un sujeto diferente. En tales supuestos, sobre la consideración de que se trata de un daño respecto del cual la sociedad no puede permanecer indiferente, si se logra acreditar la determinación dolosa en el hecho inicialmente propuesto, el acusado ha de ser juzgado exclusivamente por el daño efectivamente provocado con la misma intensidad que el primer hecho que ha intentado cometer, como si verdaderamente la acción se hubiere dirigido contra quien originalmente debió haber sido un mero espectador o podría haber permanecido ajeno de toda vinculación fáctica.

Así, por ejemplo, si $A$ con el propósito de matar dispara a $B$, pero en realidad no se trataba de $B$ sino que de $C$, o bien, dispara a $B$ con representación de la posibilidad de acertar en $C$, igualmente será responsable por el homicidio doloso de $C^{57}$ (sin diferencia de criterios entre el error en la persona o en el golpe, que en el commom law tienen un tratamiento unitario $)^{58}$. Se habla entonces de dolo de transferencia o transferred intent. ${ }^{59}$ Con todo, el supuesto ha de distinguirse del ejemplo donde la bala no logra llegar a B, sino que rompe el cristal de la tienda que está detrás, ahí no hay dolo de transferencia en relación con el delito de daños, porque en este caso la regla del common-law es que se responderá sólo por el delito de daños, sin relación concursal ideal, a diferencia de lo que ocurre con el error de tipo del Derecho continental ${ }^{60}$.

57 Dressler, Joshua, Understanding, cit. nota n. 11, p.108.

58 Regina v. Latimer, 17 Q.B.D. 359 (1886). Este caso es una antigua regla del common law originaria del Reino Unido que decidió un caso en el cual dos sujetos se trenzaron en una pelea dentro de un bar, hiriendo el acusado no sólo a quien pretendía lesionar dolosamente con un cinturón, sino que, también, de refilón golpeó además a una mujer, hiriéndola gravemente. El agresor fue acusado también de lesiones dolosas en relación a este segundo hecho, en contravención al art. $20^{\circ}$ de la antigua ley delitos contra las personas de 1861. En el juicio, Lord Coleridge fundamentó la imputación sobre la consideración que el sujeto había obrado con un "dolo general", porque es de conocimiento común que un hombre que tiene una intención contraria a derecho y que actúa maliciosamente en contra de otro si perjudica a una tercera persona, es culpable por estar realizando de modo consciente un acto ilegal. Disponible en el sitio web: http://www.publications.parliament.uk/pa/ld199798/ldjudgmt/ jd970724/gneral03.htm [visitado el 01/04/2012].

59 Ahora bien, ha de mencionarse que existe una tendencia jurisprudencial a rechazar la utilidad de la conceptualización diferenciada del dolo de transferencia. Se argumenta que para establecer que hubo dolo, y correlación entre el actus reus y el mens rea, es suficiente con acreditar en los delitos de dolo genérico la existencia de una "voluntad maliciosa". Así, JonEs, Timothy; Christie, Michael, Criminal Law, W. Green/Sweet \& Maxwell, Edinburgh, 1996, pp. 58-59.

60 Regina v. Pembliton, LR 2 CCR 119 (1874). Es otra antigua regla del common law invocada en el Reino Unido, en la que se resolvió que no hay dolo de transferencia en un caso en que un sujeto que estaba peleando en la calle y lanzó a los contendores una piedra no alcanzando su objetivo, sino que un vidrio provocando daños de un valor considerable. Las referencias al fallo y al caso se encuentran disponibles en el sitio web: http://www.publications.parliament.uk/pa/ld200203/ldjudgmt/jd031016/g-1. htm [visitado el 11/04/2012]. 
“Una aproximación al sistema de imputación subjetiva en el Derecho Penal anglosajón"

De este modo, quien intenta matar a un ser humano y consigue lo que se ha propuesto pero en una persona diferente es responsable, porque ha llevado a cabo precisamente el hecho intentado. Ahora bien, la pregunta que surge casi de modo inmediato es qué sucede en los casos en que la persona finalmente afectada no es "cualquier persona", sino un sujeto sobre la cual recae una cualidad especialmente considerada por la ley para calificar el hecho, por ejemplo, la Reina o un Juez Federal. En principio, la regla es la misma que en el Derecho continental, esto es, no se aplicará el delito cualificado, sino que se imputará, en el evento que sea posible, el delito no cualificado o figura básica en el cual sea subsumible la conducta dolosa ${ }^{61}$. Al respecto, en el caso Ford $v$. State ${ }^{62}$ se estableció como criterio la regla de que el dolo de transferencia regía tanto para los delitos regulados con dolo específico como con dolo general, pero debía hacerse una distinción en relación con los delitos especiales, porque en éstos -que son los que requieren de un dolo y un daño específico provocado a una persona cualificada- no es posible hablar de dolo de transferencia, para tales supuestos podría eventualmente concurrir una relación concursal. En consecuencia, en estos delitos de sujeto pasivo cualificado, lo importante en el Derecho angloamericano pasa a ser si el autor podía o no prever la posibilidad eventual de que se realizara un resultado diferente. Así, por ejemplo, $A$ lanza una piedra contra $B$, pero con ella lesiona a un sujeto pasivo calificado $C$, que está a corta distancia, responderá por la tentativa de lesiones en grado de dolo respecto de $A$ y por lesiones consumadas con recklessly o negligencia en relación con $C^{63}$.

\section{El dolo de oblicuidad (oblique intent) Del COMmON-LAW y EL knowingly del Derecho Penal de Estados Unidos}

Siguiendo con los ejemplos que nos han servido como referentes de aproximación conceptual, queda preguntarse qué es lo que sucede en la hipótesis iv), donde $A$ disparara a $B$ con la seria intención de herir, pero no de matar. Según las referencias indicadas anteriormente, en el Derecho continental éste sería también un supuesto de error de tipo, cuya solución podría eventualmente ir por la consideración de la concurrencia de un delito preterintencional. Pues bien, nuevamente en el Derecho angloamericano este caso se aborda bajo el trata-

\footnotetext{
61 En los delitos especiales el dolo se integra por una triple valoración que exige: primero, que el sujeto realice el actus reus descrito en todo o parte del respectivo delito; segundo, la existencia de un propósito o dolo específico de lesionar a una persona cualificada; y tercero, la conciencia del sujeto de estar realizando una conducta criminal. DRESSLER, Joshua, Understanding, cit. nota n. 11, p. 108.

62 Ford v. State, 333 Md. 682, 625 A. 2. 2d. 984 (1993). Lafave, Wayne, Modern Criminal Law : cases, comments and questions, 5ª Edición Thomson/West, St. Paul-Minnesota, 2011, pp. 124-129.

63 Singer; La Fond, Criminal, cit. nota n. 12, p. 57.
} 
miento no coincidente con el civil law, a través de una tipología específica de dolo que se conoce con la denominación de oblique intent, que se ha traducido aquí como dolo de oblicuidad y que causa en la jurisprudencia del commonlaw inconmensurables problemas vinculados a si su análisis prospectivo debe ser realizado conforme a un juicio de valoración objetivo o subjetivo ${ }^{64}$.

Ahora bien, este tipo de dolo comprende la realización consciente por parte del autor de una acción riesgosa respecto de la cual no ha tenido intención de llevar a cabo el resultado, si aquél se entiende o puede interpretarse como una consecuencia prácticamente segura de su acción ${ }^{65}$. De este modo, en el common-law se distingue entre, por un lado, el dolo directo (intención o propósito) y, por el otro, el dolo indirecto (indirect intention). Se trata, como se dijo, de una visión prospectiva del aspecto subjetivo de la imputación

${ }^{64}$ En efecto, en los últimos cuarenta años en Inglaterra se ha discutido arduamente sobre si este tipo de dolo requiere de una valoración objetiva o subjetiva en relación a la previsibilidad "casi segura" o "segura" de las consecuencias de la acción realizada por el autor. El antecedente de este postulado es DPP v. Smith, Crim LR 765 (1960), donde se acusó a un sujeto como autor del delito de homicidio con dolo de oblicuidad porque al evadir un control policial arrolló con el auto a un policía que se aferró al parabrisas. En este fallo The Huose of Lords sostuvo la imputación penal sobre las siguientes consideraciones: primero, que la muerte o las lesiones graves al policía podían ser vistas como una consecuencia altamente probable en relación a la acción desplegada; y, segundo, que desde el punto de vista de una persona razonable colocada en un momento inmediatamente anterior al hecho en la posición del autor, el riesgo se presentaba como una cuestión objetiva. The Law Commision Reported de 1967 recomendó sobre la base de este caso una revisión de este regla, establecida para el delito de homicidio y lesiones, optando por una valoración subjetiva donde el jurado fuese libre para interpretar la previsibilidad entendida como voluntad de llevar a cabo el resultado, una vez oídas todas las pruebas en el proceso. En el caso Hyam v. DPP, AC 55 (1975) The House of Lords realiza un análisis detallado del mens rea requerido para el asesinato y, en particular, del grado de previsión de las consecuencias que se estiman como necesarios para que el acusado pueda ser considerado culpable. El fallo se plantea interrogantes relativas a si el resultado debe ser una consecuencia prácticamente segura, o bien, si es suficiente con una consecuencia altamente probable. En otros términos, si basta con la mera probabilidad o con una probabilidad ordinaria, o bien, se requiere de algo más. Al respecto, se indicó que si se constata un grave riesgo de lesiones o de muerte derivado de la realización de una acción, no importa si el acusado previó o no que las consecuencias podían producirse; en consecuencia, es suficiente con una consecuencia altamente probable, con una mera "certeza moral" de la previsibilidad del resultado. Posteriormente, en los casos R v. Moloney, 1 AC 905(1985) y $R$ v. Hancock and Shankland, 1 AC 455 (1986) The House of Lords aborda el problema de la prueba de la previsión de las consecuencias y la prueba de la intención. Al respecto, se señala que el jurado debe ser invitado a valorar si el resultado era una "consecuencia natural" de la acción y, al mismo tiempo, si el acusado podía haber previsto que el resultado era una "consecuencia natural de su actuar". De este modo, la valoración de lo altamente probable se entrega a la previsibilidad del hombre común y corriente, representado por el criterio al que es invitado el jurado. Ampliamente, Blor, Duncan; PARrY, Philip, Principles of Criminal Law, $4^{\mathrm{a}}$ Edición, Cavendish Publishing Limited, London, 2000, pp. 396-404.

65 "An intention to bring about a result may be found if it is shown that the defendant thought that the result was a virtually certain consequence of his or her action". SIMESTER, Andrew; SPENCER, John; SUlLIVAN, Robert; et al., Criminal law: theory and Doctrine, 4ª Edición, Hart Publishing, Oxford, 2010, p. 132. 
que considera como determinante el conocimiento sobre las circunstancias concurrentes del hecho, en especial, en relación a la previsibilidad de las posibles consecuencias de la acción. En tal sentido, el dolo indirecto es una construcción que en el common-law atiende exclusivamente a un juicio sobre lo que el autor había o no previsto como una posibilidad altamente probable en realización con el resultado prohibido, con exclusión de toda cuestión volitiva. El aspecto cognitivo se analiza sobre la consideración de la conciencia de estar realizando una conducta objetivamente peligrosa, donde el objetivo primario del autor era lograr algo diferente al resultado, generalmente, la muerte de una persona ${ }^{66}$.

En este orden de consideraciones, un ejemplo podría graficar de mejor forma su contenido, Singer y LaFond ${ }^{67}$ sitúan en este plano el supuesto de una persona que con la finalidad de ayudar al término a la guerra destruye una fábrica de armamento nazi, que por su ubicación hace que sea inevitable el resultado de muerte para los numerosos niños que se encuentran en una escuela contigua.

A la luz del Derecho continental sorprende que casos tan disímiles como la preterintencionalidad y el dolo de consecuencias necesarias reciban un mismo tratamiento. En efecto, una asimilación conceptual desde la mera traducción del anglicismo, sin averiguación de su contenido, podría prima facie inducir a error sobre el real y verdadero alcance que tienen las categorías de imputación en el common-law. Es más, incluso el concepto de indirect intention es entendido dentro del common-law como una terminología altamente controvertible. Tal como apunta Duff ${ }^{68}$ el concepto de "intención" acá no tiene nada que ver con lo volitivo e induce a falacias interpretativas, porque no sólo se trata de prever que un daño secundario podría haber tenido lugar como consecuencia de la acción, sino que se presenta también una cuestión relativa a una total indiferencia respecto del resultado y, en consecuencia, es una categoría que podría abordarse como un caso límite de recklessness o desconsideración.

Queda todavía por indicar una diferencia terminológica importante entre el common-law y el Derecho Penal de Estados Unidos, en este punto. En el sistema americano de Derecho Penal el dolo de oblicuidad del common-law ${ }^{69}$ se incluye

\footnotetext{
${ }^{66}$ Coffey, Gerard, "Comment: Codifying the Meaning of 'intention' in the Criminal law". The Journal of Criminal Law 73, 2009, p. 396.

67 Singer; La Fond, Criminal, cit. nota n. 12, p. 58.

68 Duff, Antony, Answering for crime responsibility and liability in the Criminal law, Hart Publishing, Oxford, 2007, p. 152.

69 Singer; La Fond, Criminal, cit. nota n. 12, p. 78.
} 
en el concepto de knowing $/ y^{70}$ o conocimiento, siendo una cuestión totalmente diferenciada del intent. Se sostiene que el autor actúa con knowingly si sabe que el resultado, aunque no haya buscado conscientemente sus causas, ocurrirá como una consecuencia prácticamente segura de continuar en el mismo curso de acción. La diferencia con el actuar con dolo directo o propósito es que en esta modalidad de dolo el sujeto desea la ocurrencia del resultado, mientras que en el conocimiento el autor prevé el resultado como una posibilidad altamente probable o casi segura de sus actos, ya que, en realidad, no tiene verdaderamente en cuenta de un modo sincero si éste tendrá o no lugar ${ }^{71}$. Para afirmar su concurrencia, se exige la prueba de que el acusado, al momento de la acción, sea consciente tanto de la naturaleza de su conducta como de la existencia de las circunstancias que rodean su realización. A partir de esa prognosis, se atiende a un resultado que puede o no imputarse como una ocurrencia prácticamente certera originada en la sola realización de la conducta.

De este modo, queda claro que el sujeto que actúa con knowingly no actúa con dolo en el sentido de intencionalidad, porque no ha buscado la realización del resultado. Para acreditar esta categoría únicamente se requiere que el sujeto actúe con conocimiento de que el resultado es virtualmente seguro ${ }^{72}$, no se pide que se lo represente como una posibilidad derivada de la ejecución de la acción, porque el conocimiento, como ya se ha indicado latamente, no está unido con ningún tipo de aspecto volitivo relativo al resultado ${ }^{73}$. El conocimiento únicamente se vincula a las circunstancias concretas que rodean la realización del hecho, respecto de las que es suficiente que el sujeto "acepte o asuma, sin tener serias dudas, en el momento del hecho, que las circunstancias que lo rodean están presentes"74.

Ahora bien, según anota Taylor ${ }^{75}$ el contenido conceptual es prácticamente idéntico al del Derecho Penal alemán, donde el Direkter Vorsatz equivale a dolo directo en segundo grado -a diferencia del dolo de primer grado, denominado

70 "Section 2.02 (2) (b) (i) y (ii) Knowingly. A person acts knowingly with respect to a material element of an offense when: (i) if the element involves the nature of his conduct or attendant circumstances, he is aware that his conduct is of that nature or that such circumstances exist; and (ii) if the element involves a result of his conduct, he is aware that it is practically certain that his conduct will cause such a result". Model Penal Code, cit. nota n. 29, p. 994.

${ }^{71}$ Sección 2.02 (2) (b) (i) y (ii) del CPM. Model Penal Code, cit. nota n. 29, p. 994.

72 Simester; Spencer; Sullivan, Criminal, cit. nota n. 65, p. 147.

73 Singer; La Fond, Criminal, cit. nota n. 12, p. 60.

74 Simester; Spencer; Sullivan, Criminal, cit. nota n. 65, p. 147.

75 TAYLOR, "Concepts", cit. nota n. 33, p. 107. En igual sentido, Bohlander, Principles, cit. nota n. 33, p. 63. A modo de ejemplo, Сово; VIves, Derecho, cit. nota n. 34, p. 625. Mir PuIG, Derecho Penal, cit. nota n. 34, p. 262. Cerezo MiR, José, Curso, cit. nota n. 34, p. 146. Orts Berenguer; Gonzálezz Cussac, Compendio, cit. nota n. 34, p. 294. GorRIz Roro, Institutions, cit. nota n. 34, p. 92. 
"Absicht", "wissentlich", "wider besseres Wissen", "um zu"-y con dicha categoría se incluyen los supuestos en que el autor sabe que el resultado es una consecuencia "casi segura" de su acción, incluyéndose aquí los supuestos en que el sujeto no tiene certeza absoluta de que el hecho tendrá lugar conforme al plan de autor. Ello, porque se reconoce que nada es absolutamente seguro y, por ende, la expresión "casi seguro" es usada para indicar tanto que una mera certeza del mal es suficiente, como también, que existiría acuerdo en que el autor no tiene que "desear" el efecto secundario, porque el conocimiento es suficiente ${ }^{76}$.

En consecuencia, pese a lo que podría deducirse en una primera aproximación meramente conceptual entre ambos sistemas jurídicos, resulta que la denominación "dolo de oblicuidad" no se condice de modo exacto con las modalidades de dolo del sistema continental y, más todavía, dentro del mismo derecho anglosajón hay diferencias sobre el contenido de esta categoría. En efecto, sucede que esta modalidad de imputación abarca una serie de estados mentales que transitan en la frontera conceptual entre el dolo (intent) y la desconsideración (recklessness). En efecto, tanto la jurisprudencia, como la doctrina y el legislador a través de los tipos penales descritos en los códigos o leyes especiales, se refieren a este tipo de dolo con diferentes términos técnicos. De todos ellos ha de hacerse una mención obligatoria y especial a la ignorancia deliberada o willfull blindness, la que será desarrollada infra, porque es utilizada para explicar la forma en que se ha de acreditar el conocimiento en los casos en los que el sujeto alega desconocer que su conducta implica la realización de todos o de una parte de los elementos materiales del delito ${ }^{77}$.

76 Tal como indica Mañalich se debe evitar equiparar la definición de dolo directo de segundo grado con la doctrina del "knowledge" como estado mental requerido para el delito de asesinato en el Derecho Penal anglosajón porque, a diferencia de lo que ocurre en el Derecho continental, no se exige aquí ningún tipo de representación del resultado, siendo suficiente que el sujeto tenga conocimiento de que es una consecuencia natural de su acción, cuestión que se valora desde el punto de vista de un tercer observador imparcial. MAÑALICH, "Bases", cit. nota n. 26, p. 622 y ss. De ahí que Taylor indique que le parece un contrasentido que en el dolo de consecuencias necesarias se exija un mínimo aspecto volitivo, el Ilamado "querer débil". En efecto, pese a que coincide con el término "conocimiento", en el common-law es una cuestión con un contenido conceptual diferente. Así, mientras en Derecho continental se pide un "conocimiento" sobre la potencialidad de la acción en relación con el resultado, domina en este tipo de dolo, como bien indica el citado autor, el aspecto "cognoscitivo"; pero, al mismo tiempo, se exige la representación de la posibilidad del resultado inevitable como una consecuencia necesaria del actuar, lo que ineludiblemente implica una incumbencia de voluntad manifestada en una suerte de deber general de evitación mínima de comportamientos asociados a riesgos no permitidos. Una cosa es que domine el conocimiento, pero ello no implica la anulación total del aspecto volitivo. En cambio, en el Derecho angloamericano, la voluntad no está presente como estándar de valoración de la concurrencia de esta categoría de imputación personal. TAYLOR, "Concepts", cit. nota n. 33, p. 116.

77 En realidad, el término "willfully" es discutido por equívoco y se reserva más bien para el entendimiento del contenido de voluntariedad del actus reus. SINGER; LA FOND, Criminal, cit. nota n. 12, p. 60. 


\section{LA IGNORANCIA DELIBERADA COMO MODALIDAD DE IMPUTACIÓN SUBJETIVA (WILLFULL BLINDNESS)}

Lo indicado en el apartado anterior aparece de manifiesto del estudio del CPM, ya que se dice que este texto optaría expresamente por hacer equivalentes los términos "knowingly" -que es sinónimo al dolo de oblicuidad del commonlaw- ${ }^{78}$ con "willfull blindness" o ignorancia deliberada. Ello, porque conforme a la idea expresada en su sección 2.02 (8) el requerimiento de ceguera voluntaria se satisface, en una primera posible interpretación, a través del mero actuar con conocimiento ${ }^{79}$.

La expresión "ignorancia deliberada" hace mención a los supuestos en los cuales una persona se sitúa en un estado que imposibilita informarse sobre un determinado hecho que se corresponde con todo o parte de los elementos materiales de un delito. Se trata, como ya se ha indicado, de un supuesto que se sitúa en la línea media entre el conocimiento actual que satisface el dolo y la desconsideración ${ }^{80}$. La idea la expresan con claridad Simester, Spencer y Sullivan del modo que sigue:

"Esta doctrina se aplica en los casos en que el acusado intencionalmente elige no preguntar si algo es verdadero porque no tiene la duda real acerca de cuál ha de ser la respuesta. Su efecto es atribuirle el conocimiento de esta circunstancia al acusado. En otros términos, cuando la doctrina de la ignorancia deliberada tiene lugar, la ley trata al acusado como si obrara con conocimiento y no como si lo hiciera con desconsideración y, por ende, la intensidad del reproche es mucho mayor" ${ }^{\prime \prime 1}$.

A nivel jurisprudencial resulta esclarecedor lo resuelto en el caso Rice $v$. $S_{\text {State }}^{82}$, donde se repite esta idea al establecer que la ignorancia deliberada es un nivel de imputación subjetiva equivalente al conocimiento. A partir de tal afirmación, se realiza una interpretación según la cual, por ejemplo, la ignorancia deliberada permitiría colmar el mens rea requerido para el tipo penal de

78 Sinonimia que en el ámbito del common law se discute. SINGER; LA FOND, Criminal, cit. nota n. 12, p. 78.

79 "Section 2.02 (8) a requirement that an offense be committed willfully is satisfied if a person acts knowingly with respect to the material elements of the offense, unless a purpose to impose further requirements appears". Model Penal Code, cit. nota n. 29, p. 995.

80 Simester; Spencer; Sullivan, Criminal, cit. nota n. 65, p.147.

81 Simester; Spencer; Sullivan, Criminal, cit. nota n. 65, p. 148.

82 Rice v. State 766 A. 2d. 663, Md. Ct. Spec. App. (2000). Podgor, Ellen; Henning, Peter; Tasuttz,

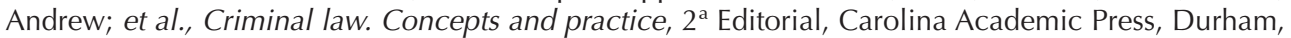
2009, p. 135. 
“Una aproximación al sistema de imputación subjetiva en el Derecho Penal anglosajón"

conducción sin licencia de conducir habilitada, objeto de la controversia en el caso citado; es un caso que se trataba de un sujeto que alegó no saber que su permiso se encontraba suspendido debido a que su cónyuge no le habría entregado la correspondencia de la administración de vehículos motorizados, que así lo indicaba. Ahora bien, se estableció como hecho probado que mientras su cónyuge se encontraba de viaje el acusado no había revisado, en un lapso de tres semanas, ningún tipo de correspondencia. El tribunal resolvió haciendo suyos los argumentos del juez Chassanow dados para sostener la parte resolutiva del caso State v. Mac Callum ${ }^{83}$. Así, se refrenda la idea de que situarse voluntariamente en un contexto de ignorancia -entendido como el no querer saber-, en relación con los presupuestos fácticos de una norma de prohibición posibilita de todas formas la imputación subjetiva del hecho, con un nivel de intensidad de reproche que equivale al dolo. Lo anterior, bajo el entendido que el sujeto actúa con el propósito de evitar o desconocer las condiciones concurrentes que habilitan el conocimiento. Dicho de otro modo, no se trata de la mera negligencia o de un mero error, sino que de una "ignorancia deliberada como forma de conocimiento".

La expresión willfull blindness o ignorancia deliberada es una terminología propia del Reino Unido. En Estados Unidos no existía un término precisamente equivalente, pero desde la segunda mitad del siglo veinte, en particular, debido a la influencia del CPM se discute latamente si está o no contenida en el parágrafo (7) de la sección 2.02 de su texto. Efectivamente, este precepto hace mención a una posibilidad excepcional de imputación, cuya controversia es si se asimila a una forma de recklessness o de knowledge ${ }^{84}$. El CPM derechamente optaría por la última, es decir, como una forma de conocimiento, indicando que este se satisface con la constatación de la existencia de una alta probabilidad de su concurrencia. Así las cosas, el conocimiento también puede ser afirmado en los casos en que el sujeto actúa sólo bajo la expectativa probable de la existencia de un hecho material, respecto del cual no se toman las providencias para cerciorarse de su no concurrencia ${ }^{85}$.

Tal como puede haberse ya advertido, se trata de una expansión del concepto de conocimiento, como categoría específica de mens rea, que requiere el saber

\footnotetext{
83 State v. MacCallum, 583 A. 2d. 250 (1991). Podgor; Henning; Taslitz, Criminal law, cit. nota n. 83, pp. 137 y ss.

${ }^{84}$ Calcote, Sarah, "Criminal Intent in Federal Environmental Statutes: What Corporate Officers and Employees Should Know", American Journal of Criminal Law 20, 1992-1993, p. 364.

85 "Section 2.02 (7) Requirement of Knowledge Satisfied by Knowledge of High Probability. When knowledge of the existence of a particular fact is an element of a high probability of its existence, unless he actually believes that it does not exist". Model Penal Code, cit. nota n. 29, p. 995.
} 
de la existencia de un determinado hecho, cuya comprobación reclama una aproximación lógica que permita deducirla con mediana claridad. Al respecto, se indica que la constatación de la ignorancia deliberada ha de realizarse mediante una prognosis subjetivo-objetiva. El primer aspecto (lo objetivo) se vincula con el mens rea requerido por el respectivo estatuto; el segundo (lo subjetivo) está referido a la valoración de culpabilidad acorde con el estándar de una persona razonable ${ }^{86}$. De conformidad a esto último, lo importante es determinar si el autor al momento de la realización de la acción podía haber tenido conocimiento de la posibilidad de estar ejecutando lo que ha decidido ignorar por completo. Es decir, que el sujeto podía haber tenido en cuenta un deber general de previsión, concretizado en la existencia de circunstancias de carácter irregular que en un hombre medio harían alojar sospechas sobre la eventualidad de estar realizando una acción que vulnera el contenido de una norma de valoración ${ }^{87}$.

En Estados Unidos se suele indicar que el caso más representativo de la moderna doctrina de la willful blindness es United States v. Jewell. ${ }^{88}$ En este proceso la $9^{a}$ Corte de Circuito de Apelación juzgó a un sujeto acusado de transportar en un compartimiento secreto de su auto cerca de cien libras de marihuana.

${ }^{86}$ Se trata de una categoría que es reconocida en el Derecho Penal norteamericano, como un sustituto del "conocimiento actual" desde fines del siglo XIX. Spurr v. United States, 174 U.S. 728, 73839 (1899), sitio web: http://supreme.justia.com/cases/federal/us/174/728/ [visitado el 20/05/2012]. Ahora bien, la doctrina del fallo se ha invocado con mayor regularidad en relación con la ley para el exhaustivo control y prevención del abuso de drogas de 1970 (the Comprehensive Drug Abuse Prevention and Control Act of 1970), que modificó el capítulo 21 U.S.C $\$ 841$ "Prohibited act A (a) Unlawful acts (2)" que sanciona a quien con "conocimiento" posea sustancias destinadas al tráfico de drogas". Federal Criminal Code and Rules, Westlaw, New York, 2000, p. 1144. A partir de una reorientación jurisprudencial que se refleja en el caso Turner v. United States 396 U.S. 398 (1970) la Corte Suprema adopta la definición de conocimiento del CPM que, según se ha visto supra, reconoce -al menos implícitamente- la ignorancia deliberada como una forma sustitutiva de conocimiento. De este modo, se limitan las defensas de los poseedores de drogas que hasta ese entonces, basándose en la idea tradicional del "conocimiento actual", invocaban el desconocimiento de la naturaleza de la sustancia. El caso disponible en el sitio web: http://supreme.justia.com/cases/federal/us/396/398/ [visitado el 18/05/2012].

87 En el Derecho angloamericano el willful blindness adquiere numerosos nombres que hacen referencia al mismo contenido conceptual, sólo por citar algunos: "willful shutting of the eyes, deliberate ignorance, studied ignorance, connivance, purposely abstaining from all inquiry as to the facts, conscious avoidance, avoidance of any endeavor to know, a conscious purpose to avoid learning the truth, studied ignorance, and knowledge of the second degree and deliberately choosing not to learn". VON KaENeL, Frans, "Willful Blindness: A Permissible Substitute for Actual Knowledge Under the Money Laundering Control Act?", Washington University Law Review, 71: 1189, 1993, pp. 1199-1200.

88 United States v. Jewel, 532 F.2d 697, 9th Cir. (1976). LAFAVE, Wayne, Modern, cit. nota n. 62, pp. 145-150. También, disponible en el sitio web: http://openjurist.org/532/f2d/697/united-states-v-jewell. visitado el 11/07/2012]. Cfr. Dressler, Cases, cit. nota n. 18, pp. 160-161. 
El estatuto legal exigía que el autor tuviese conocimiento de la presencia de una sustancia controlada, a lo que Jewell alegó desconocer que transportaba droga; sin embargo, había suficiente evidencia como para tener por establecido que era dable estimar que el imputado conocía de la existencia del referido compartimiento dentro del auto $y$, al mismo tiempo, que no podía menos que saber al momento de conducir desde México a Estados Unidos que usualmente tales gavetas son utilizadas para el contrabando de sustancias prohibidas. La Corte razonó sobre la base de la definición de knowledge del CPM, conforme al cual era posible establecer una equivalencia entre la ignorancia deliberada y el conocimiento actual de los hechos ${ }^{89}$.

A esta doctrina se le objeta su inconstitucionalidad ${ }^{90}$. En efecto, se dice que existiría violación del due process of law porque se ha expandido la interpretación del conocimiento de modo arbitrario y en perjuicio del acusado; porque en caso de dudas sobre la concurrencia real de dolo es sencillo recurrir a la ficción de ignorancia deliberada, instruyendo al jurado ${ }^{91}$ para afirmar la culpabilidad $^{92}$. El argumento se sostiene sobre la base de una infracción al principio de legalidad por aplicación de analogía contra legem, puesto que en estricto rigor sólo podría imputarse por ignorancia deliberada en el evento en que la norma penal expresamente considere este subtipo de mens rea como alternativa al conocimiento actual o real ${ }^{93}$. Por lo demás, se suele decir que es utilizada como un recurso para negar la existencia de error sobre los hechos, cuestión que puede apreciarse en el caso State v. Nations ${ }^{94}$, en el cual se imputó a un sujeto el haber contratado como bailarina de un club nocturno a una niña menor de dieciséis años, asegurando que concurría el conocimiento desde el momento en que no le pidió identificación para cerciorarse de la edad y, en consecuencia, el acusado se situó voluntariamente en una situación de

\footnotetext{
89 Von Kaenel, "Willful Blindness", cit. nota n. 87, p. 1202.

90 RobBins, Ira, "The Ostrich Instruction: Deliberate Ignorance as a Criminal Mens Rea", The Journal of Criminal Law and Criminology, Northwestern University 81:2, 1990, pp.191-234.

91 "Misleading jury instructions relying on theories such as deliberate ignorance have the possibility of diluting the knowledge requirement provided for by the statute. If lower levels of culpability are desired, the statute providing a knowing state of mind should be amended by the legislature". CALCOTE, "Criminal Intent", cit. nota n. 84, p. 366.

92 Así, United States v. Ramsey, 785 F.2d 184, 7th Cir. (1986). Disponible en el sitio web: http://openjurist.org/785/f2d/184/united-states-v-j-ramsey-j-a [visitado el 22/07/2012].

93 En esta línea, United States v. Murrieta-Bejarano, 552 F.2d 1323, 9th Cir. (1977). Ampliamente, VoN KAENEL, "Willful Blindness", cit. nota n. 87, pp. 1204-1207.

94 State v. Nations, 676 S. W. 2d. 282. Missouri Court of Appeals, Easter District (1984). DreSSLER, Cases, cit. nota n. 18, pp. 157-159.
} 
no querer conocer el contexto ni valorar la posibilidad de estar ejecutando un hecho prohibido por una norma.

Finalmente, debe indicarse que recientemente en España se ha pretendido asimilar por el Tribunal Supremo la tesis de la ignorancia deliberada, pero afirmando sorprendentemente que ella sirve para fundamentar tanto el dolo eventual como la imprudencia, cuestión que como se ha visto nada tiene que ver con el sentido que se le atribuye al willfull blindness en el common-law, donde es una modalidad de conocimiento que se acerca al dolo directo. Por lo demás, el dolo eventual es una categoría que no existe en el Derecho Penal anglosajón y, al mismo tiempo, la imprudencia aparece reservada casi de modo exclusivo para los delitos de homicidio y de lesiones, no así para supuestos de delincuencia patrimonial; ${ }^{95}$ casos a los que por excelencia el Tribunal Supremo aplica esta doctrina. De ahí que Ragués ${ }^{96}$ indique acertadamente que no puede valorarse de un modo positivo la introducción de esta categoría anglosajona en la jurisprudencia española, porque se ha hecho de modo irreflexivo y sin valorar su compatibilidad con el dolo del sistema continental.

\section{RECKLESSNESS O DeSCONSIDERACIÓN}

No existe un término que pueda definir en términos exactos el contenido de esta categoría de imputación en castellano, comúnmente los tribunales

95 Con referencias jurisprudenciales, RAGUÉS I VAlLès, Ramón, La ignorancia deliberada en Derecho Penal, Editorial Ariel-Libros Jurídicos, Barcelona, 2008, pp. 45 y ss. A modo de ejemplo, el Tribunal Supremo ha asimilado esta tesis para afirmar la responsabilidad del cooperador necesario en la estafa informática, afirmando que "el dolo del partícipe requiere el conocimiento del plan de autor, representándose mentalmente las líneas básicas, pero sin que se requiera el conocimiento de las particularidades del hecho principal". STS de 19 de julio de 2007. En igual sentido, la Sentencia de la Audiencia Provincial de La Rioja, de 21 de diciembre de 2011, núm. 13/2011). Desde este lugar, la citada STS indica que es posible argumentar la existencia de dolo eventual en la ignorancia deliberada, porque se ha fallado anteriormente en el sentido de indicar que en supuestos de delincuencia económica de tipo informático internacional "la ignorancia del resto operativo no borra ni disminuye la culpabilidad porque quienes ocupan un nivel inferior en las organizaciones son conscientes de la antijuridicidad de su comportamiento, prestando su conformidad con un evidente ánimo de enriquecimiento, ya supieran, no quisieran saber -ignorancia deliberada-, o les fuera indiferente el origen del dinero que en cantidad tan relevante recibieron". STS de 12 de junio de 2007, resolución núm. 533/2007, la cual agrega que "en la sociedad actual el acervo de conocimientos de cualquier persona de nivel cultural medio conoce y sabe de la ilicitud de una colaboración que se le pueda pedir del tipo de la que se observa en esta causa, y al respecto, hay que recordar que los recurrentes vivían en Madrid y no consta en los autos nada que pudiera ser sugestivo de un desconocimiento de la ilicitud de la colaboración que se le pedía, máxime cuando no se trataba de una colaboración gratuita sino que llevaba aneja un claro enriquecimiento personal. No hay por tanto ninguna posibilidad de derivar a ningún supuesto de error la acción de los recurrentes".

${ }^{96}$ RAGUÉs, cit. nota n. 95, p. 61. 
“Una aproximación al sistema de imputación subjetiva en el Derecho Penal anglosajón"

del common-law le suelen dar el sentido natural y obvio, conforme al uso ordinario. En una primera traducción literal sería la de "imprudencia", pero ella no se corresponde con el sentido que se le otorga al término en la dogmática del Derecho Penal continental ${ }^{97}$. En efecto, como sostienen Taylor ${ }^{98} \mathrm{y}$ Bohlander ${ }^{99}$, no hay en el civil law una expresión que pueda ser asimilable a esta categoría de imputación que es propia del common-law. Tampoco, coincide con el dolo eventual, porque como se verá en los párrafos siguientes, la recklessness no precisa de ningún elemento volitivo ${ }^{100}$. Aquí hemos preferido, tal vez arbitrariamente, la expresión "desconsideración", término utilizado por Muñoz Conde en la traducción de la Gramática de Fletcher para este anglicismo ${ }^{101}$.

En términos generales, se dice que un sujeto actúa con recklessness ${ }^{102}$ en los supuestos en que se ejecuta de un modo injustificado una acción que demuestra la no consideración un riesgo sustancial que una persona razonable hubiese tenido en cuenta al momento de la realización de un hecho, ya sea debido a su elevado peligro, o bien a las posibles consecuencias dañosas o lesivas de intereses de terceros que resultan inherentes a la rea-

97 De ahí que se diga que la traducción del término como "imprudencia" en sentido literal es equívoca de su contenido de cara a una posible aproximación conceptual con el concepto de dolo eventual del Derecho continental. MAÑALICH, "Bases", cit. nota n. 26, p. 624.

98 TAYLOR, "Concepts", cit. nota n. 33, pp. 108 y ss.

99 "Note that German law has no category of mens rea that fully equals the concept of recklessness as understood in English law". Bohlander, Principles, cit. nota n. 33, p. 63. Oo. A favor de una posible equiparación, se pronuncia Mañalich quien, desde una concepción puramente cognoscitiva, como criterio básico de la distinción entre culpa consciente y dolo eventual, sostiene que si se entiende que la imprudencia o recklessness es el nivel de imputación subjetiva por defecto, o bien, la forma básica de imputación personal por el hecho, es posible tender un puente hacia una correlación que parte de la consideración que el dolo eventual es la forma básica de dolo en el sistema continental y la recklessness, es también, el estándar mínimo constitutivo de habilitación de imputación ordinaria. No ocurre lo mismo, en ambos sistemas, con la imprudencia, debido a que la misma es, tanto en su manifestación consciente como inconsciente, una cuestión referida a deberes normativos vinculados con capacidades de evitación. MAÑALICH, "Bases", cit. nota n. 26, pp. 623 y ss.

100 Bohlander, Principles, cit. nota n. 33, p. 63. "En el dolo eventual querido es lo que el autor ha asumido". Сово; Vives, Derecho, cit. nota n. 34, p. 625. Según Mir, se entiende como el "querer" y "aceptar", pero sin aceptar la teoría del consentimiento (en relación con el resultado), sino que la de la probabilidad de la producción del resultado. MIR PUIG, Derecho Penal, cit. nota n. 34, p. 266. Por el sólo del consentimiento. Cerezo Mir, José, Curso, cit. nota n. 34, p. 147. Para una explicación de las tendencias actuales. Orts Berenguer; González Cussac, Compendio, cit. nota n. 34, p. 300. Gorriz Royo, Institutions, cit. nota n. 34, p. 93.

101 Fletcher, Gramática, cit. nota n. 1, pp. 405-406 y 413 y ss.

102 FletCher, Rethinking, cit. nota n. 20, p. 442. FletCher, Basic, cit. nota n. 15, p. 115. PIÑa RoChefort, Juan Ignacio, La estructura del delito en el ámbito jurídico del "common-law", Comares, Granada, 2002, p. 85. Bernal Del Castillo, Derecho Penal, cit. nota n. 4, p. 136. 
lización de la conducta. A diferencia del oblicue intent, no es un concepto arrancado del Derecho de daños, sino que un término propio del Derecho Penal angloamericano y constituye una categoría intermedia entre el dolo y la negligencia ${ }^{103}$.

Una definición más concreta es la que ofrecen Singer y La Fond, quienes indican que por recklessness se entiende una "decisión consciente de ignorar los riesgos inherentes a la realización del hecho, los cuales eran conocidos por el autor ${ }^{\prime \prime 104}$. En el mismo sentido, el CPM señala que una conducta se realiza con recklessly ${ }^{105}$-término que es sinónimo al de recklessness del commonlaw - si el sujeto al momento de llevar a cabo la acción previó la posibilidad de la ocurrencia del daño.

Se trata de un ámbito de imputación donde en relación con la conducta desplegada se exige que el autor conscientemente desatienda de un modo sustancial e injustificado el riesgo del cual ha participado, a través de la realización de la acción prohibida. La posibilidad de previsión está dada por la ejecución de las circunstancias concretas que rodean la realización de la conducta riesgosa, respecto de las cuales el autor ha de conocer de su existencia.

Esta cuestión referida a la desatención sustancial e injustificada del riesgo no sólo está vinculada con la acción, sino que con las circunstancias que rodean al hecho y con el resultado. El CPM toma como punto de partida del examen la desatención de la normas de mandato o de prohibición, bajo un criterio subjetivo-cualitativo, según el cual lo determinante es que desde una perspectiva ex ante se pueda afirmar que la previsión de la posibilidad estaba referida a un riesgo de real importancia. Esta cuestión difiere, en una primera aproximación, del entendimiento conceptual que se hace de ella en el Reino Unido, donde el criterio de medición fue abordado, durante un tiempo, bajo un parámetro objetivo-cuantitativo, porque se entendía que lo trascendente era la determinación de, por una parte, la existencia del riesgo y, por la otra, de

103 "Continental statutes have no comparable form. Therefore we shall begin the discussion by focusing on the classic distinction between dolus (intention) and culpa (negligence). Recklessness is a form of culpa - equivalent to what German scholars call "conscious negligence". The problem of distinguishing "intention" and "recklessness" arises because in both cases the actor is aware that his conduct might generate a specific result". FletCHER, Rethinking, cit. nota n. 20, p. 443.

104 Singer; La Fond, Criminal, cit. nota n. 12, p. 60.

105 "Section 2.02 (2) (c) Recklessly. A person acts recklessly with respect to a material element of an offense when he consciously disregards a substantial and unjustifiable risk that the material element exists or will result from his conduct. The risk must be of such a nature and degree that, considering the nature and purpose of the actor's conduct and the circumstances know to him, its disregard involves a gross deviation from the standard of conduct that a law-abiding person would observe in the actor's situation". Model Penal Code, cit. nota n. 29, p. 994. 
su potencialidad de producción del resultado, sobre la base de parámetros de probabilidad estadística o de factores de riesgo estandarizados ${ }^{106}$.

La pregunta que está siempre presente, en todo el ámbito anglosajón, es cómo abordar los supuestos en que las personas causan un daño sin la intención de provocarlo, esto es, con ausencia total de la voluntad, entendida como una decisión de realización de la acción orientada por el querer. Acá aparece el fundamento conceptual de la desconsideración o recklessness, porque ella se despoja de todo elemento volitivo y pone el acento en la atribución de responsabilidad derivada de la realización consciente de una acción riesgosa, que implica un riesgo o peligro de causación de lesión a intereses protegidos por el derecho. Si el sujeto pese a conocer el riesgo decide igualmente actuar o llevar a cabo la acción peligrosa, se dice que ha previsto la probabilidad de su ocurrencia y, por ende, debe responder a título de recklessness ${ }^{107}$.

Un ejemplo muy común podría ilustrar de mejor forma esta cuestión, se trata de un médico que inyecta a su paciente, que sufre de un ataque anafiláctico, un analgésico sin la intención de matarlo, sino que, por el contrario, con la idea de paliar su dolor. Pues bien, resulta ser que el médico no se cercioró que la persona era alérgica al medicamento, asunto que resultó ser un hecho probado en el proceso. A raíz de lo anterior, se desencadenó un incremento de la sintomatología que finalmente produjo la muerte del paciente.

De acuerdo a los conceptos apuntados, resulta razonable pensar que el médico no podía menos que saber de la concurrencia de esos riesgos, los que aparecen como inherentes a la realización de su acción. Al mismo tiempo, cualquier persona en su lugar al menos se habría preguntado sobre la posibilidad de una reacción alérgica aún mayor, incluso, sin tener en cuenta los conocimientos especiales de la medicina. Se trata ex ante de un riesgo irracional que nunca debió haber elegido asumir y, por ende, es injustificado. Tales consideraciones resultan ser suficientes para afirmar su responsabilidad penal bajo el título de desconsideración o recklessness.

Pese a lo expuesto, necesariamente debe indicarse que no todos los casos de previsión del daño implican responsabilidad a título de recklessness. En efecto, en el Derecho Penal inglés se exige, además, que el riesgo que el sujeto seria-

106 "Taken literally, this requirement might lead to a different result in the hypothetical, discussed above, where Peter Pumpkin takes the one loaded gun out of 10,000 and kills his wife. We there concluded that Peter was reckless. However, a chance of 0.001 is not really 'substantial'. To avoid the absurd result that Peter is not reckless as to death under the Code`s definition therefore requires that the word 'substantial' be read as qualitative (of real important') rather than merely quantitative ('highly probable ")". SINGER; LA FOnd, Criminal, cit. nota n. 12, p. 78.

107 Simester; Spencer; Sullivan, Criminal, cit. nota n. 65, p. 140. 
mente decide correr posea una característica cualitativa: ha de ser irracional, cuestión que se determina conforme a una primera aproximación de naturaleza preferentemente subjetiva ${ }^{108}$.

Lo anterior, a partir del ejemplo del médico quiere decir, por ejemplo, que si éste administra anestesia con conocimiento de la existencia de un riesgo leve o mínimo de que el paciente desarrolle una reacción alérgica fatal antes de llevar a cabo la operación, no será automáticamente culpable de homicidio imprudente en el evento de que el paciente muera, porque no podría afirmarse una irracionalidad cualitativa. Pero la perspectiva de lo razonable se entiende aquí siempre como una cuestión donde no importa lo que el acusado pensó, reflexionó o consideró en relación con un riesgo que estaba presente, porque, al igual que en el dolo, no interesa lo que pertenece al fuero interno, sino la valoración del significado de la acción; es decir, es una cuestión sobre lo que una persona común y corriente interpreta en el contexto de comunicación que tiene lugar al momento en que se decidió asumir ese riesgo. No se trata de lo que resultaba atendible para la persona en la situación concreta; es lo que un tercer observador colocado en la situación del autor en un momento inmediatamente anterior al hecho habría tenido siempre en cuenta ${ }^{109}$.

Hay una serie de factores que la ley tiene en especial consideración para decidir si un riesgo en una situación concreta resulta ser o no razonable. Esto incluye una valoración en términos de prognosis objetiva que, como se esbozó, incluye la probabilidad de que el riesgo ocurra, como la naturaleza y gravedad del daño que se podía provocar. Contra estas consideraciones, debería ponderarse también la probabilidad de evaluar lo que el acusado estaba tratando de hacer mientras decidió asumir el riesgo. En efecto, un riesgo considerable podría ser visto como razonable en el caso de una intervención quirúrgica que se presenta como el último recurso para salvar la vida del paciente. Pero el riesgo involucrado podría ser no aceptable si existe la alternativa de realización de un tratamiento menos riesgoso, o bien, si el propósito de la operación era meramente trivial y no se realizaron los pasos necesarios para reducir los riesgos. El estándar de una persona razonable no necesita de un umbral de probabilidad o posibilidad para ser diferenciable. Al mismo tiempo, si el riesgo es considerado mínimo o sólo como un evento extraordinario, correr ese riesgo es considerado como inobjetable. En tal sentido, incluso un riesgo leve podría ser suficiente para afirmar la presencia de recklessness, por ejemplo, si el daño que se corría el riesgo de provocar era

108 Bloy; Parry, Principles, cit. nota n. 64, p. 76.

109 Esto se basa en la idea de que no es posible evadir la ley alegando aquello que resulta ser correcto para la persona en particular. Simester; Spencer; Sullivan, Criminal, cit. nota n. 65, pp. 140-141. 
“Una aproximación al sistema de imputación subjetiva en el Derecho Penal anglosajón"

lo suficientemente serio y el acto realizado no tiene valor o interés social, es decir, no se trata de actividades riesgosas toleradas ${ }^{110}$.

\section{LAS REGLAS DE IMPUTACIÓN A TítULO DE RECKLESSNESS EN EL Derecho Penal del Reino Unido}

Hay dos definiciones de recklessness en el Derecho Penal del Reino Unido. La primera deviene de una valoración en perspectiva subjetiva conocida como Cunningham recklessness y, la segunda, se adscribe a una valoración en prospectiva objetiva denominada Caldwell recklessness. De las dos, la perspectiva subjetiva es considerada actualmente como la más importante y, conforme a ella, se actúa con recklessness: a) si el sujeto cree que su conducta dará lugar a un riesgo de daño, y b) si resulta ser irracional el correr el riesgo que se ha previsto ${ }^{111}$.

La principal diferencia entre el dolo y la recklessness está en que mientras en ambos casos el sujeto debió prever la posibilidad de realización del actus reus, en la recklessness no necesita buscar o motivarse para llevarlo a cabo. Recientemente, se ha sugerido que la previsión de la realización del riesgo no debería exigirse en todos los casos. En efecto, la tendencia actual es requerir la concreta previsión antes que el acusado entre en el estado de recklessness conforme a la regla del caso Cunningham ${ }^{112}$.

En este caso el sujeto adulteró un medidor de gas que funcionaba con monedas en una casa desocupada a fin de robar el dinero que se contenía en él. El gas escapó y se filtró a una casa adjunta, poniendo en peligro la vida de la persona que vivía allí. La referida regla indica que para decidir si un sujeto actuó o no con recklessness es preciso que haya sido razonable prever el tipo

110 El juego de la ruleta rusa debe ser atribuible a recklessness aunque las posibilidades de muerte sea de sólo una en doscientas. Simester; Spencer; Sullivan, Criminal, cit. nota n. 65, p. 141.

111 Simester; Spencer; Sullivan, Criminal, cit. nota n. 65, p.141.

112 Así, la imputación penal del aspecto subjetivo del hecho se relaciona en el derecho anglosajón con una estricta sujeción al mandato derivado del principio de legalidad, según el cual no es suficiente con averiguar si una persona obró con una determinada posición mental frente al hecho derivada del entendimiento ordinario o común de las palabras utilizadas por la ley en cada delito (sentido tradicional del mens rea), sino que es preciso que se demuestre inequívocamente que el sujeto obró con la convicción absoluta que su conducta podía provocar el resultado (sentido estatutario del mens rea). El jurado en este caso fue instruido por el Juez en el sentido de que el acusado había obrado conforme a la ley de un modo malicioso ("wickedly"); sin embargo, en la apelación el fallo fue revocado, indicándose que no era suficiente con el sentido tradicional del mens rea, porque no se podía inferir ni dolo oblicuo ni dolo de transferencia de dañar o de producir el resultado más severo y, por ende, no podía imputársele el envenenamiento; por consiguiente, se estableció como regla de derecho que el actuar "maliciosamente" requiere la prueba de que efectivamente se obró bajo la convicción absoluta de la ocurrencia probable del resultado. Regina v. Cunningham, 41 Court of Criminal Appeal, 155, 2 Q. B. 396, 2 All. Eng. Rep. 412 (1957). Dressler, Cases, cit. nota n. 18, pp. 144-145. 
específico de daño que se produjo y, pese a lo anterior, haya decidido asumir el riesgo, de cara a la posibilidad del resultado.

La regla establecida en Cunningham fue revocada temporalmente en 1981 por The House of Lords en el caso Metropolitan Police Commissioner v. Caldwe//113, donde se asume el criterio objetivo-extensivo de valoración de la previsión del riesgo del resultado. En este caso el imputado prendió fuego a la habitación de un hotel mientras se encontraba en estado de ebriedad, siendo acusado, entre otras cosas, por la comisión de un delito previsto en la sección 1(1) de la Criminal Damage Act 1971, que consagraba la posibilidad de cometer daños a la propiedad privada con recklessness. En el fallo se sostiene este nivel de imputación sobre la consideración de que el hecho realizado suponía la creación de un riesgo obvio y grave para la propiedad, con total independencia si en la realización del hecho se pensó o no en la posibilidad de la existencia concreta de dicho riesgo. Tal como indican Simester y Sullivan ${ }^{114}$ la relevancia de esta decisión judicial es la de haber creado una segunda categoría de recklessness en el Derecho Penal del Reino Unido. Ello, porque junto a la acreditación de la previsión real del riesgo (regla de Cunningham) podría, además, afirmarse su presencia en los supuestos en que el acusado haya fracasado en la representación de la existencia del riesgo, para los casos en que este se presente como una cuestión evidente u obvia, abarcando, con ello, tanto los supuestos de errónea inadvertencia como los de negligencia grosera.

Pese a que la regla de Caldwell ejerció, como indican Simester y Sullivan ${ }^{115}$, una fuerte influencia en el Derecho Penal del Reino Unido durante los años ochenta del siglo pasado, actualmente ha perdido progresivamente su vigor, en particular, debido al hecho de que se aplicó casi exclusivamente como un criterio de valoración de la imputación subjetiva del delito de conducción temeraria que fue derogado en el año 1991 (se afirmaba que el delito podía ser cometido con la ausencia total de la previsión de los riesgos inherentes al tráfico rodado). Junto a lo anterior, tampoco esta regla ha extendido su aplicación a la valoración del delito de homicidio imprudente, ni al robo o a la violación; en fin, su ámbito se restringe solamente al delito de daños, que es precisamente el supuesto enjuiciado en el caso Caldwel/ ${ }^{16}$.

Al respecto, resulta obvio que no todos los riesgos pueden ser objeto de valoración jurídico-penal. Así, conducir un auto, bajar escaleras, realizar deportes,

113 R. v. Calwell, A.C. House of Lords (1982). Clarkson, Chris; Keating, Heather, Criminal Law: Text and Materials, $3^{\text {a }}$ Edición, Editorial Sweet \& Maxwell, London, 1994, p. 161.

114 Simester; Spencer; Sullivan, Criminal, cit. nota n. 65, pp. 143-144.

115 Simester; Spencer; Sullivan, Criminal, cit. nota n. 65, pp. 143-144.

116 Clarkson; Keating, Criminal, cit. nota n. 114, pp. 162 y ss. 
son conductas que involucran riesgos que, en ciertos casos, pueden provocar por mero accidente la muerte o lesiones en otras personas; pero, en la medida en que esos riesgos no superen el nivel de lo aceptable o tolerable para el desarrollo de la vida en sociedad, no interesan al Derecho Penal ${ }^{117}$. En efecto, el riesgo se transforma en inaceptable o intolerable si supera el baremo de lo necesario para el mantenimiento de las condiciones de la vida en sociedad ${ }^{118}$.

\section{El problema de la neGligenCia COMO apéNDiCE DE LA IMPUTACIÓN SUBJETIVA EN EL COMMON-LAW}

En el common-law se suele decir que este nivel de imputación es un asunto "complejo" y "oscuro" porque habitualmente se hace referencia a la negligencia con términos bastante similares a los que se utilizan para definir la recklessness, por lo que la jurisprudencia -en cuanto a criterios- se torna a veces indistinguible, principalmente, por cuestiones derivadas del entrelazamiento del lenguaje comúnmente utilizado para una y otra categoría. Ahora bien, en esta cuestión subyace una controversia más profunda que tiene que ver con el hecho de que se cuestiona que a nivel penal pueda ser una categoría independiente de imputación subjetiva ${ }^{119}$.

Desde un punto de vista analítico, hay controversia en torno a su contenido conceptual, porque se afirma que existen al menos tres criterios que pueden operar combinadamente para atribuirle sentido terminológico. Sin perjuicio de ello, se suele decir que para afirmar su presencia en el proceso debería al menos acreditarse: primero, que el sujeto al momento de la realización del hecho actuó con un reconocimiento subjetivo del daño (es decir, que sabía que su acción conllevaba la posibilidad de producción de un resultado lesivo); segundo, que el hecho involucre un riesgo verdaderamente serio de provocar el resultado (no cualquier riesgo, sino aquel que en una persona común trae como consecuencia el rechazo en la realización de la acción); y tercero, que se pruebe que la acción conllevaba un riesgo estadístico verdaderamente importante de la posibilidad de ocurrencia del daño (asunto que se acredita, generalmente, a través del sistema actuarial). En suma, una conducta es negligente si se sitúa por debajo de lo que una persona razonable llevaría a cabo en relación con el riesgo que involucra la acción ${ }^{120}$.

117 FletCher, Basic, cit. nota n. 15, p. 119.

118 Bloy; Parry, Principles, cit. nota n. 64, p. 76.

119 Singer, Richard, "The Resurgence of Mens Rea: I-Provocation, Emotional Disturbance, and the Model Penal Code", Boston College Law Review 27:2, 1986, pp. 243 y ss.

120 Ampliamente, PIÑA Rochefort, La estructura, cit. nota n. 103, pp. 102 y ss. 
En este orden de consideraciones, el acusado sólo será responsable por los daños causados si el riesgo supera cuantitativamente el porcentaje que es exigido para el Derecho de daños. Se trata de un riesgo que virtualmente cualquier persona, no sólo la persona promedio, puede ver o percibir; en consecuencia, únicamente en los casos en que el sujeto fracasa en el reconocimiento de un riesgo que era realmente exorbitante puede ser criminalizado por el Derecho Penal, cuestión que se reduce a la aplicación de un baremo objetivo conocido como el test de riesgos que evitaría una persona razonablemente prudente (reasonably prudent person, en adelante, test de RPP).

Ahora bien, generalmente la imputación a título de negligencia requiere no sólo que se trate de una imprudencia cualitativamente diferenciable de la negligencia que puede originar responsabilidad civil, sino que, además, aparece como una cuestión reservada en la mayoría de las legislaciones del commonlaw, exclusivamente para los casos en que se comete un homicidio imprudente; sin embargo, hay una tendencia a expandir posibilidad de incriminación a otros supuestos, particularmente, en casos de delitos cometidos contra menores de edad. A falta de numerus clausus, se ha venido sosteniendo en algunas legislaciones del common-law la posibilidad de incriminación penal de todo daño negligente probado por el Derecho de daños; sin embargo, no hay claridad aún sobre cuál podría ser el estándar normativo para fundamentar, al mismo tiempo, esa responsabilidad criminal.

En tal orden de valoraciones, en el caso United State v. Garrentt ${ }^{21}$ se discutió sobre el límite entre la negligencia civil y la responsabilidad penal. Se trataba de imputar la tentativa de abordar un avión con un arma cargada en modalidad negligente; el sujetó alegó haber olvidado dicha arma en un bolsillo de una chaqueta que no utilizaba habitualmente y que había cogido la mañana en que debía abordar el vuelo porque estaba atrasado. El tribunal falló en el sentido de que el sujeto podía ser imputado sólo a título de responsabilidad civil por su error negligente y no a título de responsabilidad penal por negligencia, ya que no se trataba de un sujeto que haya fracasado en el reconocimiento del riesgo de un modo realmente exorbitante o grosero ${ }^{122}$.

121 United States v. Garrett, 471 U.S. 773 (1985). Disponible en el sitio web: http://supreme.justia.com/ cases/federal/us/471/773/ [visitado el 11/07/2012].

122 Que en el common law se establezca un sistema de imputación a título de negligencia con una relativa discrecionalidad de los jueces, no ha de verse como una demostración más de vulneración al principio de legalidad en comparación al Derecho Penal continental. Ello, porque la regla general sigue siendo la misma: la excepcionalidad del castigo de la imprudencia. Al mismo tiempo, si se observan algunas legislaciones pertenecientes al sistema continental es posible constatar que, por ejemplo, en Alemania el sistema sólo ha pasado a ser de numerus clausus desde la reforma introducida a la parte general en 1975. En efecto, como explica Bohlander hasta ese entonces la práctica jurisprudencial en el Derecho Penal alemán se limitaba a deducir del respectivo tipo penal, recurriendo tanto a su respectiva 
"Una aproximación al sistema de imputación subjetiva en el Derecho Penal anglosajón"

\section{La IMPUTACIÓN A tíTULO DE NEGLIGENCIA Y LAS TEORÍAS DE LA PENA}

La búsqueda de la justificación de la incriminación de la negligencia como modalidad de imputación subjetiva se realiza en el common-law a partir de las teorías de la pena ${ }^{123}$. Desde este lugar, algunos puntos de vista retribucionistas argumentan que la persona que ha prestado atención a la creación de un riesgo, en el fondo, no ha elegido libremente crear la situación que da origen al hecho dañoso y, por ende, no carece de culpabilidad en sentido moral. Sin embargo, otras posturas retribucionistas, basadas en la culpabilidad por el carácter, argumentan que la persona ha tenido la capacidad de dirigir su vida de un modo "no negligente" y no ha hecho uso de esa capacidad de un modo correcto en la situación concreta y, por ende, es un sujeto responsable penalmente, por no haber perfeccionado sus habilidades pasadas a fin de poder anticiparse al riesgo cuando tenga lugar. Desde un punto de vista utilitarista, tampoco existe unanimidad de fundamentos, por un lado, se afirma que la decisión de castigar penalmente las conductas negligentes puede servir para fomentar las conductas diligentes y cuidadosas, disuadiendo los futuros comportamientos criminales $y$, por el otro, se argumenta que quienes actúan negligentemente rara vez lo hacen de modo irracional, por lo que la pena no tendrá un efecto educativo y tampoco producirá un efecto real en la sociedad. A lo que se responde, del otro lado, que en realidad la negligencia deviene en punible únicamente en los supuestos en que se ha realizado un hecho sin tener en cuenta los cuidados mínimos exigibles a todos los miembros de una comunidad organizada en derecho, porque el baremo consiste en exigir que las personas tengan cuidado en relación a las acciones riesgosas que ejecutan, aunque la punición de tales comportamientos tenga un efecto marginal en los justiciables ${ }^{124}$. De esta forma, se constata lo que hemos indicado, esto es, que no hay consenso sobre cuál podría ser el fundamento real de la imputación penal a título de negligencia, ni desde las teorías de la pena ni desde su diferenciación cualitativa-cuantitativa con el derecho de daños, idea que se profundiza en los siguientes párrafos.

estructura como al propósito o espíritu del legislador, la posibilidad de imputación imprudente, lo que expiró a partir de la citada reforma, que configuró la actual redacción del §15 del Código Penal alemán. Es más, la diferencia entre el Derecho anglosajón y el continental radica en que en el primero únicamente puede ser punible penalmente la negligencia grosera, porque el resto sólo puede originar responsabilidad civil originada en el derecho de daños; en cambio, en el Derecho alemán es posible criminalizar incluso una negligencia simple. BOHLANDER, Principles, cit. nota n. 33, p. 59.

123 SINGER; LA Fond, Criminal, cit. nota n. 12, pp. 61-62.

${ }^{124}$ El problema de estos criterios está en que su excesiva inseguridad. El estándar de una persona razonable, aparentemente, normativizado y puramente objetivo, se desvirtúa con una serie de criterios valorativos generales e indeterminados que convierten el juicio de imputación en una cuestión puramente subjetiva. Bernal Del Castillo, Derecho Penal, cit. nota n. 4, pp. 140-141. 


\section{EstándAR Objetivo y SUbJETIVO dE LA VALORACIÓN DE LA NEGLIGENCIA}

Según venimos sosteniendo, se discute en el common-law cuál es el estándar de valoración que permite afirmar que una persona ha obrado de un modo negligente en materia penal. Al respecto, se sostiene que no es suficiente con un baremo objetivo entendido como la acreditación en el proceso de una probabilidad estadística de realización del resultado, sino que, también, surge junto con esa cuestión cuantitativa la necesidad de establecer, al mismo tiempo, en un plano cualitativo la relevancia que pueden tener las características personales del sujeto en la aplicación del denominado test de RPP. En efecto, ciertas características del sujeto pueden incrementar los deberes de cuidado originados, por ejemplo, en la valoración de un mayor grado de experiencia, entrenamiento o estudios, que son aspectos que comúnmente se vienen adhiriendo para la calificación del test de RPP. De esta forma, no podría exigirse el mismo grado de cuidado a un neurocirujano que a una persona común respecto de los pacientes que se encuentran a su cargo, como también, en este orden de apreciaciones han de influir las particularidades físicas propias del sujeto, por ejemplo, un grado de ceguera o de sordera -con independencia de que eventualmente pueda operar como un excusa por déficit de motivación- son aspectos que se unen al test de RPP. Estos aspectos que deben calificarse de subjetivos, influyen de un modo particularmente significativo en el grado de reprochabilidad del sujeto y se incorporan como una regla propia del Derecho Penal anglosajón, que lo diferencia en este aspecto de la acreditación primordialmente objetiva que predomina en el Derecho de daños ${ }^{125}$. Tal como explican Singer y La Fond la tendencia actual en el Derecho Penal anglosajón es hacia una mayor subjetivización del test de RPP ${ }^{126}$.

Con todo, uno de los aspectos novedosos dentro del CPM es que incluye la negligencia como el nivel de imputación subjetiva menos grave en el que puede obrar una persona en relación con la acción, las circunstancias que rodean el hecho y el resultado ${ }^{127}$. A diferencia del common-law donde es entendido como un daño provocado absurdamente, en el que la posibilidad de imputación penal, bajo un sistema abierto, depende exclusivamente de los criterios

125 Cfr. Fletcher, Basic, cit. nota n. 15, p. 117.

126 Singer; La Fond, Criminal, cit. nota n. 12, p. 64.

127 "Section 2.02. (2) (d) Negligently. A person acts negligently with respect to a material element of an offense when he should be aware of a substantial and unjustifiable risk that the material element exits or will result from his conduct. The risk must be such a nature and degree that the actor's failure to perceive it, considering the nature and purpose of his conduct and the circumstances known to him, involves a gross deviation from the standard of care that a reasonable persons would observe in the actor's situation". Model Penal Code, cit. nota n. 29, p. 994. 
de diferenciación judicial de la responsabilidad civil, en el CPM se propone que la negligencia pueda ser configurada como una categoría independiente de atribución de responsabilidad, reservada sólo para el caso de haberse cometido un homicidio (numerus clausus). Ahora bien, en este punto es posible efectuar otra distinción vinculada con el marco de penalidad sobre la base del cual se construye el homicidio negligente. Así, mientras que en el Derecho angloamericano la culpabilidad definitiva implica la imposición de una pena que en el homicidio negligente tiene en consideración el mismo marco del "manslaughter" (que consiste en matar a otro sin algunas de las circunstancias o modalidades de comisión del delito de asesinato; en suma, un homicidio simple), ${ }^{128}$ en el CPM se contempla, en cambio, una pena sensiblemente menor. Ahora bien, como ya puede advertirse, en realidad más que una regla básica o subsidiaria de imputación, la negligencia en el CPM es utilizada como una regla de mitigación de la pena del homicidio que de otra forma sería considerado igualmente como un manslaugther ${ }^{129}$.

\section{LA PRUEBA DEL MENS REA}

Una de las cuestiones más controvertidas en el Derecho Penal del commonlaw es aquella que dice relación con la forma o el método a partir del que se pueden tener por acreditados los estados mentales y su relación con la acción o el resultado. En términos generales, la prueba de los tres primeros tipos de mens rea (intent, knowledge, recklessness), se realiza a través de un proceso conocido como inferencia ${ }^{130}$, asunto al que nos aproximaremos una vez que despejemos los presupuestos que le sirven como premisas. En primer lugar, se sostiene que constituye un postulado irrenunciable, acreditado por la psicología y la psiquiatría ${ }^{131}$, la circunstancia de que es absolutamente imposible saber lo que el sujeto estaba pensando al momento de la realización de la acción. Así las cosas, para llegar a la convicción de que el sujeto ha actuado con un determinado estado mental se ha de acreditar en el proceso, tanto la acción realizada como el contexto en que ha tenido lugar, punto en el que también será importante la valoración sobre lo que han dicho los intervinientes en la relación concreta inmediatamente anterior al hecho y durante la ejecución de la acción misma. Con todo, se reconoce que se trata de un procedimiento falible, toda vez que se entiende que la regla se cumple en el momento en que el jurado es persua-

128 Bloy; Parry, Principles, cit. nota n. 64, p. 223.

131 Así, Singer; La Fond, Criminal, cit. nota n. 12, p. 78

132 Duff, Antony, Answering, cit. nota n. 68, pp. 195 y ss.

133 TAYLOR, "Concepts", cit. nota n. 33, p. 123. 
dido, desde la valoración de los antecedentes incorporados en el juicio, que un determinado estado mental que aparece, más allá de toda duda razonable, concebible en relación con la forma en que ocurrieron los hechos ${ }^{132}$.

Junto con lo anterior, ha de destacarse que un aspecto importante en la indagación de la prueba del estado mental es la cuestión relativa a los motivos subjetivos que pueda haber tenido en cuenta el autor. De modo contrario a la idea que existe en el Derecho continental en relación con el valor de los elementos subjetivos del tipo distintos del dolo, en el common-law se estima que son totalmente irrelevantes para la prueba, ni siquiera son tomados en cuenta para formar la convicción del jurado sobre si se ha obrado con dolo o sin él, porque se afirma que no forman parte de la imputación subjetiva ${ }^{133}$. Así, si el sujeto quería robar para los pobres, o bien obró por motivos raciales, religiosos, económicos o por mera diversión, es una cuestión que no tiene trascendencia valorativa para la acreditación del dolo. Sin embargo, sí podrían adquirir una relativa relevancia a la hora de determinar el dolo específico de los delitos complejos, por ejemplo, un robo con violación. En tal supuesto, junto con el dolo general de apropiarse (general intent crime) se requiere de la prueba del dolo específico de cometer un delito contra la libertad sexual (specific intent). Pero, como puede verse, se trata de elementos subjetivos que comprenden el estado mental exigido para figuras que no son de aplicación general ${ }^{134}$.

\section{CoINCIDENCIA ENTRE ACTUS REUS Y MENS REA}

La concordancia entre el actus reus y el mens rea es un presupuesto de lógica formal para afirmar la responsabilidad penal del sujeto. Ahora bien, tal

134 Singer; La Fond, Criminal, cit. nota n. 12, pp. 64-65.

135 Lo que no obsta a que puedan ser objeto de consideración por parte de la defensa, en particular, si de los motivos puede deducirse, por ejemplo, una defensa propia (self-defenses) o un estado de necesidad (duress).

136 Tanto es así que se suelen dar ejemplos referidos a este punto en relación con la eutanasia. Se dice que no hay diferencia entre quien mata a otro desconectándolo de los instrumentos que le mantienen con vida de quien dispara directamente a quemarropa. En ambos casos, se ha obrado con la intención o dolo de matar; si la acción tenía por motivo en los dos supuestos evitar que el paciente sufriera intolerables dolores, ello no resulta ser determinante a la hora de acreditar el estado mental. Ahora bien, lo anterior no obsta a que el sujeto pueda ser objeto de una penalidad menor. Con todo, los motivos que sí pueden tener algo de importancia aquí si son utilizados por el acusador con el objeto de reforzar la inferencia. Esto puede tener lugar, por ejemplo, en los casos en que de los hechos concretos inmediatos no puede deducirse el dolo (por ejemplo, A alega haber atropellado a B en caso fortuito, porque no conducía a exceso de velocidad y estaba atento a las condiciones del tránsito, pero eventualmente es posible deducir un estado mental doloso de A de hechos anteriores que sirven para valorar el contexto de relación, como puede tener lugar en hipótesis en que a la conducta del autor se le une la prueba de recelos u odiosidades personales para con la víctima). Ampliamente, SINGER; LA Fond, Criminal, cit. nota n. 12, p. 66. 
“Una aproximación al sistema de imputación subjetiva en el Derecho Penal anglosajón"

afirmación se explica en el Derecho Penal anglosajón distinguiendo el tiempo de la acción (time of the acts) del momento en que se produce el daño o el resultado (the time of the harm). En ambos ha de estar presente el mens rea en el mismo grado de intensidad de culpabilidad. Si ello no ocurre, entonces no es posible afirmar la responsabilidad criminal, al menos no a título de dolo.

Lo importante en el análisis de tiempo de referencia es el instante en que el acusado ha llevado a cabo un hecho específico en el que, concurriendo cualquiera de los grados de mens rea, pueda afirmarse que ello ha sido lo verdaderamente desencadenante del daño. Tal como se expresa, por ejemplo, en el caso People v. Decina ${ }^{135}$, resulta ser importante en el establecimiento de la coincidencia entre el actus reus y el mens rea la valoración del momento de inicio de la realización de la conducta (comenzar a conducir), porque ahí es el instante en que ha de existir algún grado de mens rea con posibilidades reales de creación de una situación de riesgo, que en el caso de referencia consistió en la eventualidad de sufrir un ataque de epilepsia, cuestión que el autor conocía como una posibilidad al momento de comenzar a conducir, por ende, debe responder por la consecuente pérdida de control del auto que desencadenó la muerte o las lesiones de los peatones. Aunque pueda afirmarse en una primera mirada que en el instante en que se produce el daño quien conduce estaba exento de responsabilidad, tal afirmación no resultará sostenible porque en el instante en que se generó la situación de riesgo (conducir) el sujeto era consciente de la posibilidad del ataque.

VIII. INTERPRETACIÓN DE LAS NORMAS PENALES Y EL MENS REA:

EL PROBLEMA DE LOS DELITOS DE RESPONSABILIDAD OBJETIVA (STRICT LIABILITY)

En el Derecho Penal angloamericano hay supuestos en que los tipos penales no contienen mención alguna al nivel de motivación normativa que es exigido para habilitar la pretensión punitiva. En tales casos, suele decirse que hay una presunción de que el legislador ha creado una figura penal en donde no es necesario que la acusación pruebe la existencia de ningún tipo de imputación subjetiva, siendo suficiente con la acreditación de la realización de causalidad entre la acción y el daño prohibido por la norma; tales delitos son conocidos bajo la categoría de tipos penales de responsabilidad objetiva o strict liability ${ }^{136}$.

En esta clase de delitos puede considerarse culpable a una persona incluso en el supuesto de que haya actuado en consideración a que estimaba razonable su conducta en la situación concreta en la que tuvo lugar. Para justificar este

137 People v. Decina, 157, N.Y.S. 2d. 558, 138 N.E. 2 d. 799 (1956), disponible en el sitio web: www. cwsl.edu/content/gudel/People\%20v.\%20Decina\%2012-18.pdf [visitado el 11/08/2012].

138 HerRING, Jonathan, Criminal, cit. nota n. 10, p. 63. 
tipo de incriminación -que en el Derecho continental podría ser considerada contraria al principio nullum crimen nulla poena sine culpa-, se dice que hay un interés público comprometido en la regulación de ciertas actividades que implican acciones inherentemente riesgosas, en las que es necesario introducir legislativamente deberes de prevención y de aseguramiento para evitar daños en la población, particularmente, en ámbitos en que es posible la ocurrencia eventual de afectaciones de valores o intereses vinculados a espacios en los que se desarrollan actividades económicas o sociales que, siendo necesarias o permitidas dentro de cierto contexto normativo, tienen o pueden tener injerencia en la esfera individual de los ciudadanos; por ejemplo, la contaminación del medioambiente, la venta de alcohol, comida y medicamentos. Se trata de ámbitos de relación en donde se asume como necesaria per se la significación jurídico-penal de ciertas conductas que ordinariamente no han pertenecido al Derecho Penal, pero que requieren de cierto refuerzo utilizando para ello la eficacia preventivo general de la pena. En efecto, como indica Herring "la amenaza del castigo penal puede alentar a las empresas a tomar resguardos de que no están infringiendo la ley"137.

La técnica legislativa se traduce en tipos penales que a nivel procesal se estandarizan con un nivel probatorio que requiere únicamente de un mínimo objetivo de acreditación de los presupuestos fácticos del actus reus, porque se pide solamente el establecimiento de la realización de un hecho voluntario y la acreditación de la participación del sujeto, sin valoración de nivel alguno de imputación subjetiva. Se argumenta a favor de este criterio diciendo que en ámbitos como el tráfico rodado sería político-criminalmente inadmisible exigir un estándar probatorio que, por ejemplo, en el delito de conducción temeraria, vaya más allá de la acreditación del hecho de que el sujeto conducía a exceso de velocidad; tal cuestión podría tener lugar si se requiriese constatar que quien ha incurrido en tal conducta sabía o conocía que sobrepasaba el límite permitido ${ }^{138}$.

Una objeción de particular relevancia se ha planteado en relación a la posibilidad de que los tipos penales de strict liability infrinjan el art. $6^{\circ}$ de la Convención Europea de Derechos Humanos. La opinión en el Reino Unido se ha resumido en los argumentos dados por Lord Hope ${ }^{139}$, quien ha explicado que no existe en el common-law la pretendida vulneración del art. $6^{\circ}$ del Convenio Europeo para la Protección de los Derechos Humanos y las Libertades Funda-

139 Herring, Jonathan, Criminal, cit. nota n. 10, p. 82.

140 Herring, Jonathan, Criminal, cit. nota n. 10, p. 82.

141 R v. G, opinión de 18 junio 2008, UKHL 37. Disponible en el sitio web: http://www.publications. parliament.uk/pa/ld200708/ldjudgmt/jd080618/rvg-1.htm [visitado el 18/05/2012]. 
"Una aproximación al sistema de imputación subjetiva en el Derecho Penal anglosajón"

mentales, por cuanto únicamente se establece en su texto el derecho al due process of law (debido proceso legal) y, en particular, en lo relativo al segundo numeral de la citada norma que consagra el derecho que le asiste al acusado a la presunción de inocencia hasta que la culpabilidad haya sido legalmente declarada, ello porque la referida norma está vinculada a garantías de orden procesal, en concreto, al derecho a un racional y justo procedimiento (fair trial) y no a los aspectos sustantivos de la descripción legal de la conducta punible, como es el caso de que esté redactada con exclusión de requerimientos de estados mentales específicos, ya sea en relación a la totalidad, o bien, a una parte de la descripción legal. En suma, se trata de una regla relativa a las garantías que tienen derecho a exigir los justiciables de la administración de justicia penal en un proceso penal adversarial, pero no se refiere a cuestiones vinculadas con el derecho sustantivo interno.

A diferencia de lo que ocurre en el Reino Unido, en Estados Unidos se ha discutido a nivel jurisprudencial y doctrinal la constitucionalidad de esta forma de atribución de responsabilidad. Al respecto, se indica que pese a que no sea posible estimar un acuerdo en la Corte Suprema sobre este punto ${ }^{140}$, en los últimos pronunciamientos al respecto (por todos, Clark v. Arizona ${ }^{141}$ ) se sostiene que las legislaturas de los Estados tienen la autoridad soberana, tanto para definir y limitar el mens rea, como las defensas que pueden invocarse por parte del acusado y, todo lo anterior, sin restricción alguna.

Ahora bien, la pregunta es en qué casos puede decirse que estamos en presencia de un tipo penal de strict liability, porque el legislador no lo dice expresamente, ni suele agrupar estos delitos de modo expreso; pese a ello, se sostiene que hay algunos datos que permiten averiguarlo. En concreto, se dice, que no es suficiente que a nivel preceptivo se guarde silencio respecto al grado de mens rea (intent, knowledge, recklessness), sino que es necesario que de un modo claro ${ }^{142}$ se pueda deducir que existe tal presunción. Al respecto, se

142 Vid., con amplias referencias, SINGER; LA FOnd, Criminal, cit. nota n. 12, pp. 74-75.

143 Clark v. Arizona, U. S. 5/5966 (2006). Disponible en el sitio web: http://www.law.cornell.edu/supct/ html/05-5966.ZS.html. [visitado el 18/05/2012].

144 En B v. DPP, Crim LR 403 (2000), The House of Lords indicó que el estatuto contenido en la Indecency with Children Act 1960, guardaba claramente silencio sobre todo tipo de requerimiento de mens rea, en concreto, de dolo o conocimiento de la edad de la víctima. El caso se trataba de un sujeto que había incitado a una joven menor de 14 años a realizarle una felatio in ore. El acusado alegó en su defensa un error de hecho (mistake) respecto de uno de los elementos del estatuto legal: la edad del sujeto pasivo, indicando que al momento de realizar la propuesta se había representado, por la constitución física, que se trataba de una muchacha mayor de 14 años. El fallo estimó que no había motivos para deducir que el respectivo tipo penal requería la acreditación de conocimiento por parte del sujeto y, por ende, ninguna prueba de mens rea era exigible al acusador y la alegación de la defensa no podía ser acogida. HeRRING, Jonathan, Criminal, cit. nota n. 10, pp. 90-91. 
distingue entre, por una parte, los delitos que de un modo absoluto no requieren mens rea respecto de ninguna parte de la descripción típica (formally strict liability) y, por otra parte, los delitos que no conllevan prueba de culpabilidad únicamente en relación con algunos aspectos de la descripción delictiva (substantively strict liability). La diferenciación efectuada por Duff ${ }^{143}$, se sintetiza con el ejemplo que sigue:

"La responsabilidad penal por la posesión no autorizada de drogas reguladas en virtud de la sección 1 (1) de la Ley de Prevención del Uso Indebido de Drogas de 1964 era absoluta, en el sentido de que no podía alegarse que la sustancia que estaba en mi poder era o no una droga ilegal. En cambio, bajo la Ley de Abuso de Drogas de 1971 la responsabilidad es estricta, porque quien está en posesión de una sustancia controlada ahora puede obtener la absolución si se demuestra que no sabía ni sospecha ni tenía motivos para sospechar que se trataba de droga"144.

Con todo, pese a que suele decirse que el recurso a esta técnica de tipificación penal es excepcional, lo cierto es que según apunta Herring ${ }^{145}$ más de la mitad de los delitos que son conocidos por la Crown Court en el Reino Unido corresponden a supuestos típicos en donde no es necesaria la prueba total o parcial del mens rea.

Tal como puede ya inferirse, los delitos de strict liability no deben ser comprendidos como delitos de responsabilidad absoluta (absolute liability), porque si bien no exigen la prueba de ninguno de los estados mentales que configuran el mens rea, ya sea en relación con toda o una parte de los elementos de la descripción normativa, no excluyen la reclamación de la ausencia de culpabilidad, porque a menudo el mismo estatuto establece la posibilidad de invocar la defensa de diligencia debida (due diligence). De este modo, el acusado puede ser absuelto si demuestra haber obrado en cumplimiento del deber de cuidado objetivo que le era exigible en la situación concreta en que se encontraba al momento de realizar el hecho y, además, porque se ha establecido la posibilidad de invocar la defensa de actuación de terceros (act third party defence), según la cual el acusado puede exonerarse de culpabilidad probando que el actus reus es el resultado de la conducta llevada a cabo por otra persona que ha obrado induciéndola a error ${ }^{146}$.

143 Duff, Antony, Answering, cit. nota n. 68, p. 233.

144 Duff, Antony, Answering, cit. nota n. 68, p. 233.

145 Herring, Jonathan, Criminal, cit. nota n. 10, p. 81.

146 Tampoco se excluye la posibilidad de invocar defensas generales como la legítima defensa o el automatismo (fuerza irresistible), porque ambas no afectan el contenido del mens rea. HERRING, Jonathan, Criminal, cit. nota n. 10, p. 81. 
“Una aproximación al sistema de imputación subjetiva en el Derecho Penal anglosajón”

No es suficiente con la ambigüedad o el silencio para entender que se está en presencia de un delito de strict liability. Al respecto, se argumenta que la interpretación de los tipos penales debe realizarse sobre la base de una ponderación de intereses de política criminal, donde la inclusión o exclusión del requerimiento de prueba estatal del mens rea, en los supuestos en que no aparece del todo claro, ha de realizarse racionalmente, siempre del modo más restrictivo posible y contra la presunción de ausencia de requerimientos de estados mentales en los casos dudosos, para lo cual junto con el análisis restrictivo ha de tenerse en cuenta el contexto de la ley, en especial, si dentro del mismo estatuto aparece un estado mental específico para una materia similar (in a pari materia) que posibilita una interpretación conjunta y armónica, teniendo también en cuenta la penalidad que ha dispuesto el legislador para dos o más conductas que versan sobre el mismo contenido de prohibición ${ }^{147}$. Este postulado encuentra sus cimientos en el principio de legalidad expresado en la regla del significado natural y obvio (plain meaning), conforme a la cual los jueces en la construcción de los estatutos han de aproximarse a su interpretación, primero, restringiendo la intromisión arbitraria del legislador en la vida de los ciudadanos y, segundo, requiriendo que el legislador sea claro particularmente cuando la libertad de los ciudadanos está en juego. Conforme a la regla de lenidad o condescendencia (rule of lenity) ${ }^{148}$ los estatutos han de interpretarse a favor de la libertad del acusado en los supuestos en los cuales el legislador no haya establecido claramente todo el contenido de la prohibición, o bien, no sea posible desprenderlo del texto legal.

147 Al respecto, supongamos que hipotéticamente la ley penal incriminara los siguientes supuestos: a) "El que ilegalmente vendiere cannabis será sancionado con una pena de multa de mil dólares". Como puede verse se trataría, al menos preliminarmente, de un tipo penal de strict liability; pero, en el contexto interpretativo aparece otro delito que contiene el mismo presupuesto de valoración, es conminado con la misma pena y, además, exige expresamente "conocimiento", como estado mental, que denominaremos supuesto b) "El que con conocimiento vendiere ilegalmente heroína será sancionado con una pena de multa de mil dólares". Conforme a los criterios de interpretación explicados supra no podría decirse con claridad que el tipo penal del supuesto a) sea ya un caso de strict liability. Ahora bien, las dudas se incrementarían todavía más en el evento de que el supuesto b) estableciera como pretensión de pena consistente en la privación de libertad, porque ahí cabría inferir que el legislador ha querido exigir un mens rea en un nivel particularmente intenso (por ejemplo, el "conocimiento") para la venta de heroína. Ampliamente, con ejemplos, SINGER; LA FOnD, Criminal, cit. nota n. 12, pp. 68-69.

148 Sobre las tres versiones de esta regla, ZACHARY, Price, "The Rule of Lenity as a Rule of Structure", Fordham Law Review 74: 4, 2004, pp. 889 y ss. La Corte Suprema de Estados Unidos ha sostenido que ella queda reservada, en particular, para las situaciones en que persiste una duda razonable acerca de lo que la norma pretendía regular, incluso después recurrir al lenguaje o a su estructura, o bien, a la historia legislativa y a las motivaciones de política criminal. Moskal v. United States 498 U.S. 103 (1990). Disponible en el sitio web: http://www.law.cornell.edu/supct/html/89-0964.ZS.html [visitado el 11/04/2012]. 
A favor del establecimiento de los delitos de strict liability, se alega que más que una categoría de atribución de responsabilidad meramente objetiva, o bien, sin referencia a distinciones entre normas de valoración y de determinación es, simplemente, una mera técnica legislativa que eleva a la categoría de infracciones penales meras cuestiones que deberían merecer una respuesta punitiva desde el Derecho de daños, o mejor aún, desde el Derecho administrativo ${ }^{149}$. Pero las opiniones contrarias estiman que constituyen una renuncia al principio de injerencia mínima del sistema penal en las relaciones sociales, que se traduce en una inversión del peso de la prueba, aunque no excluyan totalmente la posibilidad de invocar defensas. Con ello se demuestra que una cuestión es que no se pida un nivel específico de imputación a modo de estado mental y otro asunto es que se excluya derechamente toda oportunidad de alegación de falta de autodeterminación en la realización del hecho. De ahí que habría que mirar con cierta reserva la afirmación de Bohalander ${ }^{150}$ en el sentido de que esta categoría de delitos no podría ser asumida en ningún caso por el Derecho continental, porque allí rige de modo irrestricto el mandato limitativo derivado del nullum crimen, nulla poena, sine culpa.

\section{IMPUTACIÓN SUBJETIVA POR DEFECTO}

Despejada la idea de que la ausencia de mens rea pueda dar lugar a la presunción de un delito de strict liability, corresponde averiguar qué sucede en los restantes supuestos, donde no se ha mencionado ningún tipo de mens rea; en otros términos, bajo qué nivel de responsabilidad han de analizarle los elementos de la respectiva descripción típica si no es posible afirmar la presunción de responsabilidad objetiva. Sobre este punto no hay acuerdo. En efecto, a nivel jurisprudencial es posible constatar la existencia de dos importantes decisiones de la Corte Suprema de Estados Unidos en las que, una vez descartada la existencia de un delito de strict liability, se sostiene que la culpabilidad no puede ser afirmada a no ser que se pruebe que el acusado obró al menos con conocimiento ("knowingly") respecto de los elementos materiales de la descripción estatutaria. Esta afirmación contiene dos niveles de análisis, por una parte, un

149 Bernal del Castillo, Derecho Penal, cit. nota n. 4, pp. 102-106.

150 Bohlander, Principles, cit. nota n. 33, p. 20. En efecto, este punto de vista lo ha puesto de manifiesto Piña al indicar que es una cuestión que depende de las funciones que se le asignen al Derecho Penal. De esta forma, si se parte de la consideración de que resulta legítimo atribuir responsabilidad por infracción de normas que obligan a conducirse de un modo determinado, o bien, por el establecimiento de deberes derivados de la evitación de peligros y de resultados, esta técnica legislativa resultaría ser coherente y hasta cierto punto justificable. En cambio, si se asume que el Derecho Penal no puede reprochar las conductas humanas, sino una vez que se ha materializado una decisión libre y voluntaria, no hay justificación posible. PIÑA ROCHEFORT, La estructura, cit. nota n. 103, pp. 73-76. 
“Una aproximación al sistema de imputación subjetiva en el Derecho Penal anglosajón"

aspecto relativo a la interpretación por defecto de imputación explícitamente descrita en el estatuto, donde se recurre a la fundamentación de la decisión del caso Staples v. United States ${ }^{151}$ y, por otra parte, en cuanto al conocimiento como categoría de mens rea exigido respecto de los elementos esenciales del aspecto objetivo de la descripción, pero no en lo referente a cuestiones accidentales, asunto que aparece en el fallo $X$-Citement Video v. United States ${ }^{152}$.

En el caso Staples v. United States se establece de modo categórico que, descartada la presunción de responsabilidad objetiva y a falta de mención expresa en el estatuto de algún tipo de mens rea, es necesario establecer el nivel de imputación subjetiva por defecto, entendiendo que ello se cumple con la prueba de que el acusado actuó con knowingly respecto de cado uno de los elementos esenciales del estatuto federal. ${ }^{153}$ El caso se trataba de un sujeto imputado por la comisión de un delito de omisión del deber de informar la posesión de un rifle que podía ser modificado para disparar de modo automático, ya que conforme al estatuto todos los propietarios de armas de fuego automáticas o que son susceptibles de ser alteradas para adquirir dicho carácter, tenían el deber de comunicar su posesión; el imputado reconoció que el arma se encontraba bajo su señorío, pero indicó que no tenía conciencia de la posibilidad de adulteración y su consecuente potencialidad peligrosa, al respecto la Corte Suprema señala no sólo que es necesario algún nivel de mens rea teniendo en consideración la elevada pena para este tipo de delitos y, por ende, desvirtuada la presunción de responsabilidad objetiva y a falta de mención expresa se requiere "un conocimiento actual de los hechos", lo que se indicó del modo que sigue:

"Una pena severa es un factor que tiende a sugerir que el Congreso no tenía la intención de eliminar el requisito del mens rea, en tal caso debe aplicarse la presunción habitual de que el imputado debe conocer los hechos que hacen que su conducta sea ilegal"154.

Ahora bien, la sentencia del caso X-Citement Video v. United States dispone que la prueba del conocimiento se exige en relación con todos los elementos

151 Staples v. United States, 511 U.S. 600 (1994). Dressler, Cases, cit. nota n. 18, pp. 170, 176-177. Disponible en el sitio web: http://www.law.cornell.edu/supct/html/92-1441.ZO.html. [visitado el 18/05/2012].

152 X-Citement Video v. United States, 513 U. S. 64 (1994). Disponible en el sitio web: http://www. law.cornell.edu/supct/html/93-723.ZO.html [visitado el 22/07/2012].

153 Aunque la mayoría de las Cortes de Circuito de Apelaciones de Estado Unidos, como apuntan Singer y La Fond, además, de la mayoría de los jueces de los respectivos Estados adoptan el criterio de que la imputación penal en este caso requiere al menos la prueba de recklessness entendida como "previsión actual de la posibilidad de la realización del daño criminal". SINGER; LA Fond, Criminal, cit. nota n. 12, p. 73.

154 Dressler, Cases, cit. nota n. 18, pp. 170 y 176-177. 
materiales que envuelven el contenido de la norma de prohibición. De este modo, el estándar de prueba del aspecto subjetivo se eleva no sólo para aquella parte de la disposición directamente entrelazada en términos gramaticales con el tipo de mens rea especificado en el estatuto, sino que se expande a todo el aspecto descriptivo del mismo. En el caso citado se abordó la imputación por venta de material pornográfico infantil, y se dispuso, desde un punto de vista analítico, que la palabra "knowingly" envolvía no sólo la prueba de que el sujeto sabía que vendía material pornográfico, sino que, al mismo tiempo, el requerimiento de la acreditación procesal de que éste tenía el conocimiento de que en la elaboración de dicho material habían sido utilizados menores de edad. Y todo ello en relación con lo preceptuado en el \$2252 del United State Code $^{155}$. Lo importante de todo lo anterior, es que la Corte Suprema junto con indicar que el conocimiento es el nivel base de imputación penal subjetiva señala, además, que todos los tipos de mens rea han de tenerse en cuenta, a nivel interpretativo, sólo en relación con los aspectos materiales de la norma. Como puede verse, no hay una correspondencia entre lo fallado en los casos citados y la propuesta de nivel de imputación por defecto que realiza el CPM, donde se indica que la imprudencia o recklessness constituye la forma básica de imputación subjetiva.

\section{Consideración final}

De lo expuesto es posible indicar que, en términos generales, el sistema de imputación subjetiva del Derecho Penal anglosajón es esencialmente el resultado de una compleja evolución jurisprudencial y doctrinal, donde la idea central es el entendimiento del derecho como un saber práctico. En tal sentido, las categorías que constituyen el mens rea han ido objetivándose mediante la incorporación de estándares que combinan parámetros cualitativos y cuantitativos de acreditación y prueba de los hechos en el proceso penal. Lo anterior se entiende desde la progresiva renuncia al entendimiento del aspecto subjetivo del hecho como un proceso interno, es decir, como una cuestión perteneciente a la realidad psíquica del sujeto, para pasar a conceptualizarlo como hecho externo que depende de la interpretación del sentido de la acción,

155 "(a) Any person who: (1) knowingly transports or ships in interstate or foreign commerce by any means including by computer or mails, any visual depiction, if- $(A)$ the producing of such visual depiction involves the use of a minor engaging in sexually explicit conduct; and (B) such visual depiction is of such conduct; (2) knowingly receives, or distributes, any visual depiction that has been mailed, or has been shipped or transported in interstate or foreign commerce, or which contains materials which have been mailed or so shipped or transported, by any means including by computer, or knowingly reproduces any visual depiction for distribution interstate or foreign commerce or through the mails, if- (A) the producing of such visual depiction involves the use of a minor engaging in sexually explicit conduct; and (B) such visual depiction is of such conduct". Federal Criminal, cit. nota n. 86, pp. 775-776. 
constándose un estándar de valoración y atribución de responsabilidad claro, preciso y ampliamente conocido, pese a las tensiones internas derivadas de las fronteras conceptuales de ciertas categorías como la ignorancia deliberada o la imprudencia, cuya discusión de contenidos y límites se encuentra aún en pleno desarrollo.

\section{BibLiografíA}

Aмвоs, Kai, "Dogmática jurídico-penal y concepto universal de hecho punible", Política Criminal 5, 2008.

Амвоs, Kai, Temas de Derecho Penal internacional y europeo, Marcial Pons, Madrid, 2006.

Bernal del Castillo, Jesús, Derecho Penal Comparado. La definición de delito en los sistemas anglosajón y continental, Ariel-Libros Jurídicos, Barcelona, 2011.

Blor, Duncan; PARrY, Philip, Principles of Criminal Law, $4^{\text {a }}$ Edición, Cavendish Publishing Limited, London, 2000.

Bohlander, Michael, Principles of German Criminal Law, Vol. 2, Hart Publishing, Oxford, 2009.

Bustos Ramírez, Juan; Hormazabál Malarée, Hernán, Lecciones de Derecho Penal. Parte General, 2ª Edición, Trotta, Madrid, 2006.

Calcote, Sarah, "Criminal Intent in Federal Environmental Statutes: What Corporate Officers and Employees Should Know", American Journal of Criminal Law 20, 1992-1993.

Carnevali Rodríguez, Raúl, Derecho Penal y Derecho sancionador de la Unión Europea, Comares, Granada, 2001.

Cerezo Mir, José, Curso de Derecho Penal español, t. II, 6a Edición, Tecnos, Madrid, 1998.

Clarkson, Chris; Keating, Heather, Criminal Law: Text and Materials, $3^{a}$ Edición, Editorial Sweet \& Maxwell, London, 1994.

Cobo del Rosal, Manuel; Vives Antón, Tomás Salvador, Derecho Penal. Parte General, 5ª Edición, Tirant lo Blanch, Valencia, 1999.

Coffey, Gerard, "Comment: Codifying the Meaning of 'intention` in the Criminal law", The Journal of Criminal Law 73, 2009.

Díaz Pita, María del Mar, "La presunta inexistencia del elemento volitivo en el dolo y su imposibilidad de normativización", Revista Penal 17, 2006.

Dressler, Joshua, Cases and materials of Criminal Law, $3^{\text {a }}$ Edición, Thomson West, St. Paul, 2003.

Dressler, Joshua, Understanding Criminal Law, $2^{\text {a }}$ Edición, Editorial Matthew Bender \& Co., New York, 1992. 
DubBer, Markus Dirk, "The Promise of German Criminal Law: A Science of Crime and Punishment", German Law Journal 7, 2005.

Dubber, Markus Dirk, The Sense of Justice in Penal Law. Empathy in Law and Punishment, New York University Press, New York-London, 2006.

Duff, Antony, Answering for crime responsibility and liability in the Criminal law, Hart Publishing, Oxford, 2007.

FEIJÓO SÁnCHEZ, Bernardo, "La distinción entre dolo e imprudencia en los delitos de resultado lesivo. Sobre la normativización del dolo", Cuadernos de Política Criminal 65, 1998.

Fletcher, George, Basic Concepts of Criminal Law, Oxford University Press, New York-London, 1998.

FletCher, George, Gramática del Derecho Penal, Francisco Muñoz Conde (trad.), Hamurabi, Buenos Aires, 2008.

FletCHeR, George, Rethinking Criminal Law, 2ª Edición, Oxford University Press, New York-London, 2000.

GonzÁlez Cussac, José Luis, "Dolus in re ipsa", en Carbonell Mateu, Juan Carlos; González Cussac, José Luis, et al. (dirs.); Cuerda Arnau, María Luisa (coord.), Constitución, Derechos fundamentales y sistema penal (semblanzas y estudios con motivo del setenta aniversario del profesor Tomás Salvador Vives Antón), Tirant lo Blanch, Valencia, 2009.

Gorriz Royo, Elena, Institutions of Criminal law, General Part, Universitat de València, Valencia, 2012.

HART, Herbet, "Legal Responsability and Excuses", Punishment and Respons-

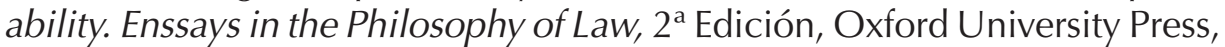
New York-London, 2008.

HerRING, Jonathan, Criminal law, $6^{a}$ Edición, Plagrave Macmillan, New York, 2009.

HrusChKA, Joachim, "Imputation", Bringham University Law Review 669, 1986.

Jakoвs, Günther, Derecho Penal: Parte General: fundamentos y teoría de la imputación, Joaquín Cuello Contreras y José Luis Serrano González de Murillo (trad.), 2a Edición Marcial Pons, Madrid, 1997.

Jones, Timothy; Christie, Michael, Criminal Law, W. Green/Sweet \& Maxwell, Edinburgh, 1996.

Kadish, Sanford; Schulhofer, Stephen; Paulsen, Monrad, Criminal law and its processes: cases and materials, $4^{\text {a }}$ Edición, Little Brown \& Co. Boston, Boston, 1983.

Kaplan, John; Weisberg, Robert; BInder, Guyora, Criminal Law. Cases and Materials, $5^{\text {a }}$ Edición, Aspen Publishers, New York, 2004. 
LAfave, Wayne, Modern criminal law: cases, comments and questions, $5^{a}$ Edición Thomson/West, St. Paul-Minnesota, 2011.

Laurenzo Copello, Patricia, Dolo y conocimiento, Tirant lo Blanch, Valencia, 1999.

Mañalich Raffo, Juan Pablo, "Bases para una teoría comparativa del hecho punible", Revista Jurídica de la Universidad de Puerto Rico 75:2, 2006.

Martínez-Buján Pérez, Carlos, "El concepto "significativo" de dolo: un concepto volitivo normativo", Problemas actuales del Derecho Penal y de la Criminología. Estudios penales en memoria de la profesora María del Mar Díaz Pita, Tirant lo Blanch, Valencia, 2008.

Matus Acuña, Jean Pierre, La transformación de la teoría del delito en el Derecho Penal internacional, Ariel-Libros Jurídicos, Barcelona, 2008.

Mir PUIG, Santiago, Derecho Penal. Parte General, $8^{\mathrm{a}}$ ed. Reppertor, Barcelona, 2008.

Morillas Cuevas, Lorenzo, Derecho Penal. Parte General. t. II. Vol. 1, Dykinson, Madrid, 2008.

Orts Berenguer, Enrique; González Cussac, José Luis, Compendio de Derecho Penal Parte General, 3ª Edición, Tirant lo Blanch, Valencia, 2011.

Perrón, Walter, “¿Son superables las fronteras nacionales del Derecho Penal? Reflexiones acerca de los presupuestos estructurales de la armonización y unificación de los diferentes sistemas de Derecho Penal", Revista de Derecho Penal y Criminología 2, 1998.

Piña Rochefort, Juan Ignacio, La estructura del delito en el ámbito jurídico del "Common-law", Comares, Granada, 2002.

Podgor, Ellen; Henning, Peter; Taslitz, Andrew et al., Criminal law. Concepts

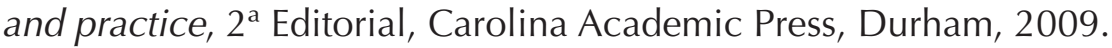

Radbruch, Gustav, "Jurisprudence in the Criminal Law", 18 J. Comp. Legis. \& Int'l L. 3d ser. 212, 1936.

Ragués i Vallès, Ramón, "Consideraciones sobre la prueba del dolo", Revista de Estudios de la Justicia 4, 2004.

Ragués i Vallès, Ramón, El dolo y su prueba en el proceso penal, Universidad Externado de Colombia, Bogotá, 2002.

Ragués i Vallès, Ramón, La ignorancia deliberada en Derecho Penal, Editorial Ariel-Libros Jurídicos, Barcelona, 2008.

RoBBINs, Ira, "The Ostrich Instruction: Deliberate Ignorance as a Criminal Mens Rea", The Journal of Criminal Law and Criminology, Northwestern University 81:2, 1990.

RobInson, Paul; DubBer, Markus, "The American Model Code: A Brief Overview", New Criminal Law Review 10:3, 2007. 
Roxin, Claus, Derecho Penal. Parte General, t. I. Diego Luzón Peña; Miguel García Conlledo, et al. (trads.), Civitas, Madrid, 1997.

Schamalleger, Frank, Criminal law today: an introduction with capstone cases, $3^{a}$ Edición, Prentice Hall, New Jersey, 2006.

Silva SÁnchez, Jesús María, "Los principios inspiradores de las propuestas de un Derecho Penal europeo. Una Aproximación crítica", Revista Penal 3, 2004.

Silva SÁnchez, Jesús María, Aproximación al Derecho Penal contemporáneo, Bosch Editor, Barcelona, 1992.

Simester, Andrew; SPEnCER, John; Sullivan, Robert et al., Criminal law: theory and

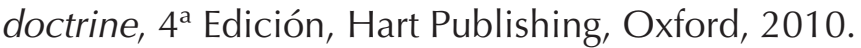

SINGER, Richard, "The Resurgence of Mens Rea: I-Provocation, Emotional Disturbance, and the Model Penal Code", Boston College Law Review 27:2, 1986.

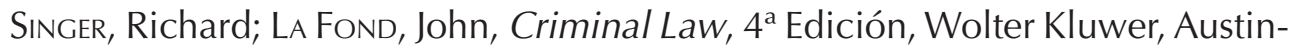
Boston, 2007.

TAYLOR, Greg, "Concepts of intention in German Criminal Law", Oxford Journal of Legal Studies 24: 1, 2004.

VIADA, Natacha, Derecho Penal y globalización. Cooperación penal internacional, Marcial Pons, Madrid, 2009.

Vives Antón, Tomás Salvador, "Reexamen del dolo", Problemas actuales del Derecho Penal y de la Criminología. Estudios penales en memoria de la profesora María del Mar Díaz Pita, Tirant lo Blanch, Valencia, 2008.

Vives Antón, Tomás Salvador, Fundamentos del sistema penal. Acción significativa y derechos constitucionales, $2^{\text {a }}$ Edición, Tirant lo Blanch, Valencia, 2011.

Von Kaenel, Frans, "Willful Blindness: A Permissible Substitute for Actual Knowledge Under the Money Laundering Control Act?", Washington University Law Review, 71: 1189, 1993.

ZACHARY, Price, "The Rule of Lenity as a Rule of Structure", Fordham Law Review 74: 4, 2004.

Zugaldía Espinar, José; Pérez Alonso, Esteban, Derecho Penal. Parte General, $2^{\text {a }}$ Edición, Tirant Lo Blanch, Valencia, 2004.

\section{Documentos:}

Federal Criminal Code and Rules, Westlaw, New York, 2000.

Model Penal Code, Official Draft 1962, American Law Institute, en: Dressler, Joshua, Cases and materials of Criminal Law, $3^{\text {a }}$ Edición, Thomson West, St. Paul, 2003. 


\section{Tabla de sentencias}

$B$ v. DPP, Crim LR 403 (2000).

Clark v. Arizona, U. S. 5/5966 (2006).

DPP v. Smith, Crim LR 765 (1960).

Hyam v. DPP, AC 55 (1975).

Morissete v. United States, 342 U.S. 246 (1952).

Moskal v. United States 498 U.S. 103 (1990).

People v. Decina, 157, N.Y.S. 2d. 558, 138 N.E. 2d. 799 (1956).

People v. Hood, 462 P.2d 370 (1969).

R. vi. G., opinión de 18 junio 2008, UKHL 37.

R. v. Hancock and Shankland, 1 AC 455 (1986).

R. v. Moloney, 1 AC 905 (1985).

R. v. Calwell, A.C. House of Lords (1982).

Ratzlaf v. United State, (92-1196), 510 U.S. 135 (1994).

Regina v. Cunningham, 41 Court of Criminal Appeal, 155, 2 Q. B. 396, 2 All. Eng. Rep. 412 (1957)

Regina v. Latimer, 17 Q.B.D. 359 (1886).

Regina v. Pembliton LR 2 CCR 119 (1874).

Rice v. Stat, 766 A. 2d. 663, Md. Ct. Spec. App. (2000).

Sentencia de la Audiencia Provincial de La Rioja, 21 de diciembre de 2011 (núm. 13/2011).

Spurr v. United States, 174 U.S. 728, 738-39 (1899).

Staples v. United States, 511 U.S. 600 (1994).

State v. MacCallum, 583 A. 2d. 250 (1991).

State v. Nations, 676 S. W. 2d. 282. Missouri Court of Appeals, Easter District (1984).

STS de 12 de junio de 2007.

STS de 19 de julio de 2007.

United States v. Garrett, 471 U.S. 773 (1985).

United States v. Jewel, 532 F.2d 697, 9th Cir. (1976).

United States v. Murrieta-Bejarano, 552 F.2d 1323, 9th Cir. (1977).

United States v. Ramsey, 785 F.2d 184, 7th Cir. (1986).

X-Citement Video v. United States, 513 U. S. 64 (1994).

Sitios de Internet

http://openjurist.org/532/f2d/697/united-states-v-jewell.

http://openjurist.org/785/f2d/184/united-states-v-j-ramsey-j-a 
http://supreme.justia.com/cases/federal/us/396/398/

http://supreme.justia.com/cases/federal/us/471/773/

http://www.law.cornell.edu/supct/html/05-5966.ZS.html

http://www.law.cornell.edu/supct/html/89-0964.ZS.html

http://www.law.cornell.edu/supct/html/92-1196.ZO.html

http://www.law.cornell.edu/supct/html/92-1441.ZO.html

http://www.law.cornell.edu/supct/html/93-723.ZO.html

http://www.publications.parliament.uk/pa/ld199798/ldjudgmt/jd970724/gneral03.htm

http://www.publications.parliament.uk/pa/ld200203/ldjudgmt/jd031016/g-1. $\mathrm{htm}$

http://www.law.cornell.edu/supremecourt/text/342/246

www.cwsl.edu/content/gudel/People\%20v.\%20Decina\%2012-18.pdf 